\title{
DISMISSALS WITHIN THE CONTEXT OF COLLECTIVE BARGAINING
}

\author{
Thanduxolo Qotoyi \\ BA MDip(HR) MA(HR) LLM(Labour Law) \\ Lecturer, Walter Sisulu University
}

Adriaan van der Walt

Bluris BA(Hons) LLB

Associate Professor

Head: Labour and Social Security Law Unit

Nelson Mandela Metropolitan University

Port Elizabeth

\section{SUMMARY}

Competitive forces in the market force employers to change the way they operate their businesses. The changes that employers have to make often demand an alteration of the employees' terms and conditions of employment. By law employers are not permitted to effect changes to the employees' terms and conditions of employment unilaterally. They have to obtain the consent of the affected employees. This is where collective bargaining fits in. The employer has to negotiate with the employees. One way in which, through the process of collective bargaining, an employer can exert pressure on the employees to accept the changes is to effect a lock-out.

Under the Labour Relations Act 28 of 1956 within the context of a lock-out, an employer was permitted to use conditional dismissal as a bargaining weapon. This conditional dismissal had to be coupled with an offer of re-employment should the employees accept an employer's demand. In essence, the lock-out had a bite in the form of the conditional dismissal. This made the lock-out quite effective.

The 1995 Labour Relations Act prohibits in no uncertain terms the use of a dismissal as a means of compelling employees to accept an employer's demand in any matter of mutual interest. Within the collective bargaining context, dismissal is not a legitimate option. The employer only has the lock-out as a tool of compulsion. The definition of a lock-out in terms of this Act does not accommodate the use of dismissal. This makes the lock-out option to be less potent than it was under the 1956 Labour Relations Act.

However, employers are permitted to dismiss on operational grounds, provided that they follow a fair procedure. Terms and conditions of employment greatly feature in the operational requirements of a business. If the employees' terms and conditions of employment are not responsive to the operational requirements of the business and they are unwilling to accept changes to those terms, the employer has the right to dismiss them. The employer will not be dismissing the employees as a way of inducing them to accept the changes. He will instead be dismissing them on the basis of operational requirements. 
The question that then arises is how should a dismissal that is intended to compel employees to accept an employers demand (falling within section 187(1)(c) of the 1995 Labour Relations Act) be distinguished from a dismissal that is genuinely based on operational requirements as contemplated by section 188(1)(a)(ii). The question arises whether the fact that section $187(1)$ (c) explicitly prohibits the use of dismissal within the context of collective bargaining gives rise to some tension with section 188(1)(a)(ii) which categorically gives employers the right to dismiss on operational grounds.

The decision of the Labour Appeal Court in Fry's Metals v NUMSA has stated that there is no tension whatsoever between the two sections. The court has also ruled that the dismissals that are hit by section 187(1)(c) are those dismissals that are accompanied by an offer of re-employment. According to the court, this offer is indicative of the real purpose of the employer, namely to compel employees to accept his demand. Dismissals not accompanied by an offer of re-employment are on the other hand a true reflection of the fact that the employer is indeed dismissing the employees for operational requirements.

This literal interpretation of the meaning and scope of section 187(1)(c) has the potential of opening the floodgates. Instead of resorting to the use of the lock-out to secure the agreement of employees in the collective bargaining process, employers now have a potent tool in the form of a dismissal. As long as the employer makes it abundantly clear that the dismissal is final and irrevocable, he is free from the claws of section $187(1)(\mathrm{c})$.

Given the fact that the lock-out option is not always effective, employers may find it hard to resist the temptation to use the threat of permanent dismissal as a bargaining chip. It is an option that is emasculated by the fact that if an employer initiated a lockout the use of replacement labour is prohibited. The threat of not just a conditional dismissal but a permanent one may force employees to capitulate to the employer's demand during negotiations. This would effectively render negotiations about changes to terms and conditions of employment a farce. The employer would have an upper hand.

The implications of this narrow interpretation are quite far-reaching. The long held view that dismissal is not a legitimate weapon of coercion in the collective bargaining process is under serious challenge. Only conditional dismissals are illegitimate in the collective bargaining arena. Permanent dismissals are permitted. This negates the very purpose of the collective bargaining process.

This study seeks to examine the anomalies that flow from this interpretation of the meaning of section $187(1)(\mathrm{c})$. The study further investigates if this interpretation is not at odds with what the legislation really intended to achieve by enacting this clause.

The study also explores ways in which the sanctity of collective bargaining could be restored. Recommendations are made to that effect.

\section{INTRODUCTION}

In an increasingly competitive market, employers may be forced to introduce changes to the employees' terms and conditions of employment in order to survive, increase profitability, enhance efficiency and respond to the technological changes. The need to effect change to the employees' terms and conditions of employment could be triggered by the fact that the existing terms are no longer responsive to the employers' operational needs. The importance of the responsiveness of the employees' terms and conditions of employment to the employers' operational requirements was aptly captured 
by Zondo in Freshmark (Pty) Ltd v Commission for Conciliation, Mediation \& Arbitration. ${ }^{1}$

An employer enters into a certain contract of employment with an employee on certain terms and conditions because he or his business or undertaking requires an employee who is prepared to work in accordance with those terms and conditions in order to meet the operational requirements of the business or undertaking. When that contract of employment as a whole or some of its terms and conditions can no longer serve or no longer suit the operational requirements of the business, a valid reason for the employer to terminate that contract of employment occurs.

That there could be situations where there may be a need to effect changes to the employees' terms and conditions of employment was also emphasized in A Mauchle (Pty) Ltd t/a Precision Tools v NUMSA, where the court held that "employees do not have a vested right to preserve their working obligations unchanged as from the moment when they first began to work". 2

Notwithstanding the fact that there may be instances where an employer may be forced to effect changes to the employees' terms and conditions of employment, it is important to note that the employer is not allowed to introduce such changes without following fair processes. For instance, when effecting such changes, the employer cannot act unilaterally. The Labour Relations Act 66 of 1995 strictly prohibits introduction of unilateral changes. According to section 64(4) of the Labour Relations Act the following consequences flow from such an action:

- The employees may go on strike and require the employer not to effect the change.

- If the change has been effected, the employer may be requested to restore the status quo.

It is therefore imperative that when introducing changes to the employees' terms and conditions of employment, consent of the affected employees must be obtained. This is where the collective bargaining process plays an important role.

According to Salamon ${ }^{3}$ collective bargaining can be defined as a method of determining the terms and conditions of employment and regulating the employment relationship, which utilizes the process of negotiation between representatives of management and employees and results in an agreement which may be applied uniformly across a group of employees. The Constitution of the Republic of South Africa categorically states that every trade union, employers' organization and the employer have the right to engage in collective bargaining. ${ }^{4}$ The importance of the collective bargaining process in labour relations is further underlined by the fact that one of the

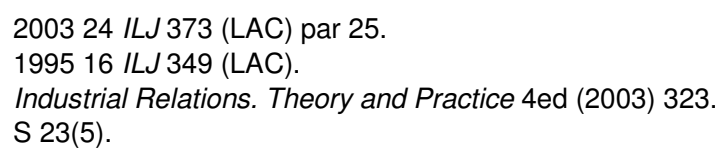


primary objects of the Labour Relations Act 66 of 1995 is to promote orderly collective bargaining. ${ }^{5}$

Collective bargaining mainly focuses on settling terms and conditions of employment, and other matters of mutual interest between employers and employees. Matters of mutual interest can broadly be regarded as including issues relating to terms and conditions of employment like employee compensation, remuneration and service benefits. In Rand Tyre and Accessories (Pty) Ltd \& Appel v Industrial Council for the Motor Industry (Transvaal), Minister of Labour, and Minister for Justice ${ }^{6}$ the concept of "matters of mutual interest between the employer and employee" was defined as "whatever can be fairly and reasonably regarded as calculated to promote the well-being of the trade, must be of mutual interest to them".

In the labour relations sphere disputes are normally categorized into two types, the disputes of interest and disputes of right. In Gauteng Provinsiale Administrasie $v$ Scheepers ${ }^{7}$ a dispute of right was defined as a dispute over an already existing right that could be located in a statute, collective agreement or contract of employment. Disputes of right are resolved through arbitration and adjudication. Dismissal is permitted in the dispute of rights sphere. In SADTU $v$ Minister of Education ${ }^{8}$ the concept of a dispute of interest was explained as referring to a dispute relating to proposals for the creation of new rights or the diminution of existing rights and is normally resolved by collective bargaining. The process allows the involved parties to make use of power play in the form of strikes and lock-outs when there is an impasse. In the process of collective bargaining dismissal as a weapon of pressurizing the other party is strictly forbidden. Disputes arising from matters of mutual interest are regarded as interest disputes.

Within the context of collective bargaining one of the tools that employers have at their disposal is the lock-out. Various pieces of legislation have acknowledged this notion. Both the 1956 Labour Relations Act and the 1995 Labour Relations Act permitted the use of a lock-out in the collective bargaining process. The only point at which they differed was in relation to the use of dismissal by the employer within the process of effecting a lockout.

Under the 1956 Labour Relations Act employers were allowed to make use of tactical dismissal or temporary dismissal within the context of a lockout. $^{9}$ This enabled employers to resort to dismissal as long as that dismissal was intended to force employees to comply with any demands or proposals relating to terms and conditions of employment. It is very important to note that under the 1956 Labour Relations Act the dismissals that were permitted within the context of collective bargaining were those that clearly had a purpose of compelling employees to accept demands relating to terms and

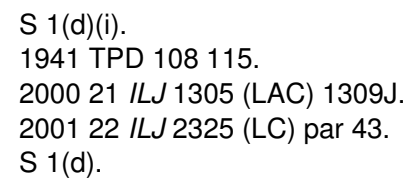


conditions of employment, in the sense that they were subject to being withdrawn should the employees accept an employer's demand.

However, the 1995 Labour Relations Act strictly forbids the dismissal of employees in order to compel them to accept a demand in respect of any matter of mutual interest between the employer and employees. ${ }^{10}$ Such a dismissal is regarded as being automatically unfair and has serious consequences for the affected employer. This is intended to protect employees against unfair dismissals where an employer may try to strengthen its hold by threatening to dismiss employees if they do not agree to its demands during the collective bargaining process. Allowing an employer to resort to dismissal during the collective bargaining process would effectively weaken the position of employees. One of the options that an employer can use of as a way of reinforcing his demands is a lock-out ${ }^{11}$ but not dismissal during the collective bargaining process. Disputes of interest must be resolved through power play.

Proposed changes to the terms and conditions of employment can be classified as falling within the category of matters of mutual interest, thereby giving rise to interest disputes which have to be resolved through collective bargaining. In this regard, the employer cannot introduce the changes unilaterally. He also cannot dismiss the employees as a way of compelling them to accept the proposed changes, as this would constitute an automatically unfair dismissal. Instead he may resort to power-play. The employer may have to negotiate with the employees in order to effect changes to their terms and conditions of employment. Alternatively, the employer may resort to a lock-out.

However, there is no guarantee that the options legally available to the employer may produce the desired results. Negotiations may take a long time and may even fail to yield any result for the employer as the employees may be unwilling to accept the proposed changes. The lock-out may also be costly, particularly an offensive lock-out where an employer is not allowed to make use of replacement labour. ${ }^{12}$

Under these circumstances the question is whether the employer who must respond to the market demands or face financial ruin can resort to dismissing those employees who are unwilling to have their terms and conditions of employment changed so that they can be responsive to the operational requirements of the business. Issues around terms and conditions of employment normally fall within the ambit of matters of mutual interest which have to be resolved through the process of collective bargaining. In the same vein, the very same terms and conditions of employment issues (which fall within the collective bargaining process ambit), like change in working shifts, can give rise to a situation where an employer, due to factors like globalization, stiff competition or profit-making could be compelled to introduce changes to the enterprise in order to meet

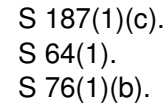


operational requirements of the enterprise. In this case, the competing interests of the employees' right to employment and the employers' right to run his business successfully would be involved. That an employer has a right to run his enterprise successfully through responding to market changes was succinctly captured in Schoeman $v$ Samsung Electronics (Pty) $L t d^{13}$ this way:

"An employer in the private sector needs to be able to survive and prosper economically. To do this the employer must meet changed market circumstances and be competitive. To meet the changes of the market adaptations are required. An employer needs the flexibility to deploy, reasonably, quickly and efficiently, the resources at the employer's disposal."

If employees refuse to accept those changes which are necessary for the business to survive, the business may not be able to meet its operational requirements and in that case the employer may be forced to dismiss those employees. In this case the employees would be dismissed not as a way of compelling them to accept a demand in respect of a matter of mutual interest but because they are unable to meet the operational requirements of the enterprise. The Labour Relations Act permits employers to dismiss on the grounds of operational requirements, provided that a fair procedure is followed. ${ }^{15}$

In essence matters of mutual interest may in certain circumstances become issues of right. A dispute that may have started as a matter of mutual interest dispute (normally resolved through collective bargaining) may suddenly become a rights dispute where an employer can justifiably resort to dismissal. This paradoxical situation was succinctly captured in Schoeman $v$ Samsung Electronics (Pty) $L t d,{ }^{16}$ when Landman J stated that:

"An employer may not dismiss employees in order to compel acceptance of a demand but this does not prevent the employer resorting to dismissal for operational requirements in a genuine case.

This poses serious challenges when it comes to balancing the interests of the employer to run an enterprise efficiently and in some cases even to resort to dismissal to ensure the survival, profitability and efficiency of the enterprise against the employees' right to employment. The employeremployee relationship is characterized by inherent inequality with the employer in a very powerful position. By effectively prohibiting dismissal and only permitting resort to power-play in respect of interest disputes involving matters of mutual interest, the collective bargaining process seeks to introduce some balance in the relationship. However, an employer is entitled to run his business in a prosperous way and this may entail effecting changes to terms and conditions of employment when the market forces so

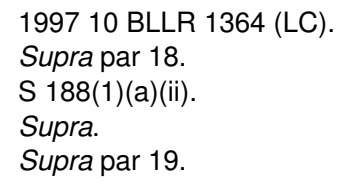


demand. In line with the purpose of the 1995 Labour Relations Act which is to advance economic development as well as social justice, ${ }^{18}$ the challenge is to strike a balance between the two competing interests.

This situation where an issue (concerning terms and conditions of employment) which is a matter of mutual interest and which gives rise to an interest dispute which is resolved through collective bargaining, but can at the same time become a right dispute where the employer would have a right to resort to dismissal, poses a dilemma in the labour relations sphere. This brings about tension between sections 187(1)(c) and 188(1)(a)(ii) of the 1995 Labour Relations Act. Section 187(1)(c) forbids employers from dismissing employees in order to compel them to accept a demand in any matter of mutual interest between the employer and employee. It can be said this section was intended to get rid of the dismissal lock-out effectively which was one of the options that was available to the employer in the collective bargaining process under the 1956 Labour Relations Act. ${ }^{19}$ On the face of it this section appears to outlaw dismissal effectively even if it is temporary within the context of collective bargaining. Section 188(1)(a)(ii) permits employers to dismiss on operational requirements grounds. This means that even within the context of collective bargaining, where for instance an employer wants to change the terms and conditions of employment and the employees' refuse to accept those changes the employer may dismiss employees on operational grounds, subject to the condition that the procedures laid out in section 189 are followed.

This paradoxical situation has the potential of giving rise to a situation where, despite the noble intention of outlawing dismissal within the context of collective bargaining in the form of a dismissal lock-out, which section 187(1)(c) might have been enacted for, employers may still resort to dismissal on the grounds of operational requirements which is fully permitted by section 188(1)(a)(ii) of the 1995 Labour Relations Act. This possibility was succinctly expressed in Contemporary Labour Law, where in relation to the 1995 Labour Relations Act (referred to as the NLRA or the New Labour Relations Act) this observation was made:

"The NLRA has done away with the concept of the dismissal lock-out. This concept was one of the tools of management to change terms and conditions of employment and the manner in which workplace activities were performed. With the demise of this mechanism the attention of employers will turn to that other mechanism, which has always been something of a companion to the dismissal lock-out, namely dismissal for operational requirements" ${ }^{20}$ (authors' emphasis).

Cheadle also highlighted this tension in the following way:

"Section 187(1)(c) makes the classic lock-out dismissal automatically unfair. An employer may no longer dismiss employees to compel them to accept new terms and conditions of employment. But how different is that from dismissing

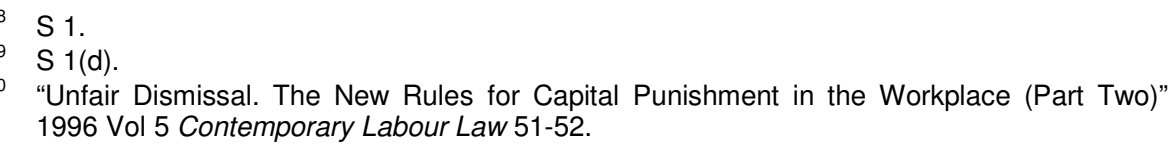


an employee on grounds of operational requirements because the employer needs to change a term or condition of employment and the employee refuses to agree to it? This is precisely the question that Landman $\mathrm{J}$ grappled with in SA Chemical Workers Union v Afrox Ltd (1998) 19 ILJ 62 (LC) 67. He recognized that the purpose is the same - to change terms and conditions of employment. The reasons for changing terms and conditions of employment is the same - operational requirements. He suggested somewhat diffidently, that the difference may lie in the procedure to be adopted in effecting the dismissal an operational requirements dismissal has to follow a detailed procedure. But if the reason (compelling an employee to accept new terms and conditions) is automatically unfair, then complying with section 189 cannot transform the dismissal into a fair one."

A problem arises from the tension between these two sections. How does one distinguish between a dismissal compelling employees to accept new conditions of employment on the one hand (section 187(1)(c)), and a dismissal that is effected for operational reasons because an employee refuses to accept proposed changes to conditions of employment (section 188(1)(a)(ii))?

This difficulty was hinted by Landman $\mathrm{J}$ in Schoeman $v$ Samsung Electronics (Pty) $L t d{ }^{22}$ when he noted that whilst an employer is not allowed to dismiss an employee in order to compel acceptance of a demand in relation to terms and conditions of employment, this does not prevent the employer from resorting to dismissal for operational requirements in a genuine case. The question, then, is how to distinguish dismissals which are genuinely necessitated by operational requirements from those whose real aim is to compel employees to accept a demand.

Noting this difficulty Cheadle et $a f^{23}$ suggested that the best way out of this "conundrum" is to limit ambit of the phrase "operational requirements" to what he termed "redundancy situations which are brought about by economic causes" as opposed to structural causes which result in employees being dismissed and replaced with subcontractors or other employees.

Also, Thompson ${ }^{24}$ argued that the tension between the two sections has the potential to blur the line between matters of mutual interest that should be resolved through collective bargaining (where dismissal is strictly prohibited) and those matters that fall within the domain of rights disputes where dismissal is permitted. Noting this intersection between matters of mutual interest and matters of right and the ensuing complexity, he suggested that retrenchments within the context of proposed changes to terms and conditions of employment should be confined only to situations that are meant to ensure the survival of a business and not be allowed where the purpose is to increase profitability. According to him, whilst profitability can be classified as an operational requirement, it is not such a

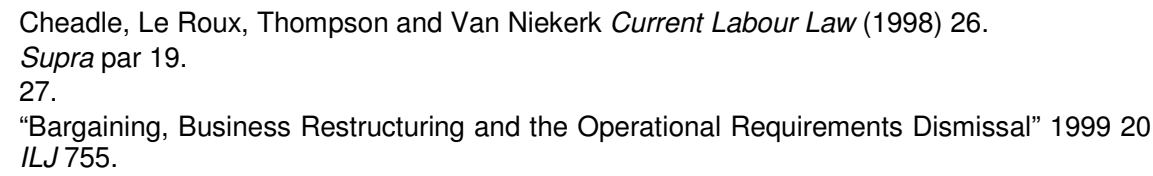


compelling requirement when compared to the survival of a business. He emphasized his point as follows:

"When the contest between management and labour is 'purely' over the wage-
work bargain - in other words the substantive terms of the next collective
agreement - dismissal will never be permissible. The 'for profits' termination
offends against $s$ 187(c). An employer may argue, however, that not a quest
for profit but sheer operational requirements oblige a particular economic
outcome, even to the point of sanctioning the discharge of those who hold out.
But the Labour Court should lean against the result that follows a dispute on a
wage-work deal to escape the protected zone of collective bargaining. When
in exceptional circumstances the case for migration is made, the employer
must still overcome a formidable fairness hurdle in the judicial process.".5

Both these suggestions were based on the appreciation of the fact that the line that distinguishes a dismissal that is based on section $187(1)(c)$ and that based on section 188(1)(a)(ii) is a very fine one. To put it bluntly, both dismissals emanate from the same cause, a desire to introduce changes to terms and conditions of employment.

However, the court in Fry's Metals (Pty) Ltd $v$ National Union of Metalworkers of South Africa ${ }^{26}$ has expressly rejected the notion that there is tension between the two sections. The court has also rejected out of hand the argument that the phrase "operational requirements" within the context of changing terms and conditions of employment should be strictly limited to situations where the survival of a business is at stake. It is against this background that the following questions arise:

- How will the sanctity of the collective bargaining process where parties engage with each other without the fear of dismissal be protected?

- Given the clear dichotomy between disputes of rights and disputes of interest and how these disputes are resolved, how will this dichotomy which has been relied upon by courts in the past be maintained?

- How will the possibility of employers commencing their participation in the collective bargaining process with the threat of dismissing the employees if they do not agree to the demands relating to changing their terms and conditions of employment, thereby abusing the collective bargaining process, be obviated?

- There may be a very fine line between a dismissal related to compelling an employee to accept a demand about changing the terms and conditions of employment and a dismissal relating to terms and conditions of employment on grounds of operational requirements. A wrong call by the employer can have serious consequences like having the dismissal branded as an automatically unfair dismissal, whilst another dismissal effected for the very same purpose may be found to be merely unfair. Given the harsh consequences for a dismissal that is automatically unfair, how will fairness principles be adhered to when meting out punitive measures for dismissals which may for all intents and purposes

25 Thompson 199920 ILJ 755-766.

26200324 ILJ 133 (LAC). 
be emanating from the same source and having the same purpose, albeit couched differently?

- What will be the future implications for collective bargaining and indeed labour relations?

This study seeks to address these concerns. Paragraph 2 below deals with the legal position in South Africa in relation to dismissals within the context of collective bargaining. Paragraph 3 below analyses case law pertaining to dismissals emanating from the process of collective bargaining. Paragraph 4 below looks critically at the implications of the Fry's Metals (Pty) Ltd $v N_{N M S A^{27}}$ judgment. Paragraph 5 below looks at ways of possibly resolving the apparent tensions between section 187(1)(c) and section 188(1)(a)(ii) of the Labour Relations Act 66 of 1995. Paragraph 6 below provides a conclusion to the discussion.

\section{THE LEGAL POSITION IN SOUTH AFRICA IN RELATION TO DISMISSALS WITHIN THE CONTEXT OF COLLECTIVE BARGAINING}

\section{The 1956 Labour Relations Act}

Under the 1956 Labour Relations Act the employer was allowed to use dismissal as a way of putting pressure on employees to accede to his demands in the process of collective bargaining. This was possible through section 65(d) of that Labour Relations Act according to which an employer was allowed to dismiss employees (temporarily) in order to compel them to accept demands or proposals concerning terms and conditions of employment. This form of dismissal was classified as a dismissal lock-out and was conditional in the sense that once employees accepted the demands relating to terms or conditions of their employment, the dismissals would be reversed. The dismissal had to be strictly subject to being withdrawn upon the acceptance of the employer's demand by the employees. In essence, the lock-out option which is one of the options that an employer can resort to in the collective bargaining process was further strengthened by the availability of a conditional dismissal. This catered for the possibility that within the context of collective bargaining employees may refuse to accept changes to their terms and conditions of employment which are necessary for the efficiency of an enterprise and negotiations may not yield the desired results. In terms of the 1956 Labour Relations Act a lockout was defined in the following way:

“'Lock-out' means any one or more of the following acts or omissions by a person who is or has been an employer -

(a) the exclusion by him of anybody or number of persons who are or have been in his employ from any premises on or in which work provided by him is or has been performed; or

20032 BLLR 140 (LAC). 
(b) the total or partial discontinuance by him of his business or of the provision of work; or

(c) the breach or termination by him of the contracts of employment of any body or number of persons in his employ; or

(d) the refusal or failure by him to re-employ any body who have been in his employ, if the purpose of that exclusion, discontinuance, breach, termination, refusal or failure is to induce or compel any persons, who are or have been in his employ or in the employ of other persons -

(i) to agree to or comply with any demands or proposals concerning terms and conditions of employment or other matters made by him or on his behalf or by or on behalf of any other person who is or has been an employer; or

(ii) to accept any change in the terms or conditions of employment; or

(iii) to agree to the employment or the suspension or termination of the employment of any person" ${ }^{\prime 28}$ (authors' emphasis).

From this definition of a lock-out it is clear that an employer could make use of a dismissal within the context of collective bargaining. What is clear is that the dismissal had to have a purpose and also be conditional. It had to be intended to compel the employee to accept demands related to matters of mutual interest and be subject to being withdrawn the moment the employees accepted the employer's demands to effect changes to their terms or conditions of employment. ${ }^{29}$ Therefore, it can be said that within the context of collective bargaining dismissals were permitted provided that they were functional to collective bargaining. In this way the employer was to a certain degree permitted to change the terms or conditions of employment unilaterally through using the termination lock-out option.

In $K$ Ngubane $v$ NTE Limited $^{30}$ the court made the following observation in relation to a lock-out dismissal:

"The Act requires that the contract must be terminated with the purpose to induce acceptance of a demand or proposal ... The requirement that the termination must have this purpose will be met if the employer, simultaneously with the termination, offers each employee employment on terms and conditions of employment commensurate with his final offer ... The offer must remain open for acceptance for a specified time (which has to be a reasonable time) or an indefinite time. The offer, if it is indefinite, would lapse when it is withdrawn provided that it must remain open for acceptance for a reasonable time ... The employer would in effect couple termination with an offer to obtain re-employment. Whilst termination of employment is final, the lock-out ends only when the offer of re-employment expires ...,

Therefore, an employer was well within his rights to dismiss employees conditionally who were unwilling to accept changes to their terms or conditions of employment, as a way of inducing them to accept those changes. This dismissal was subject to the employer's making an offer of reemployment should the employees accede to his demands. This would make the dismissal fair. Such a termination of employment (conditional)

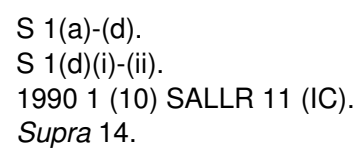


constituted a lock-out in terms of the Labour Relations Act 28 of $1956{ }^{32}$ This principle was also emphasised in National Union of Metalworkers of SA v Eveready $S A$ (Pty) $L t d{ }^{33}$ where it was held that the employer had acted fairly when he terminated the employees' services and offered to re-employ them if they accepted his offer.

It is clear that within the collective bargaining context, employers could resort to conditional dismissal legitimately as a weapon of compelling employees to accept their demands, provided that the dismissals were subject to being withdrawn if the demands were accepted by the employees. If the dismissals were not coupled with an offer of re-employment upon acceptance of the offer, then such dismissals were held to be outside the ambit of the lock-out definition and consequently unfair. In CCAWUSA v Game Discount World $\mathrm{Ltd}^{34}$ an employer, after having failed to reach an agreement in negotiations about wages and other terms and conditions of employment, dismissed the employees. The employer indicated that the dismissals were final and irrevocable and not subject to being withdrawn upon acceptance of the demands. The court held that the dismissals fell outside the ambit of the lock-out definition and were therefore unlawful. The court made the following observation:

"There can be no lock-out if the act forming part of the lock-out was not performed for one of the specified purposes. The employer who introduces a lock-out must do so to achieve a purpose. In casu the act which purportedly introduced the lock-out was the dismissal on 11 October 1989. That dismissal was, and was intended to be final and irrevocable. The individual applicants were not dismissed to compel or induce them to accept respondent's demand. The fact that the notice to the employees was for that purpose, does not assist the respondent. The termination should have been for that purpose."

Also, in CWIU $v$ Indian Ocean Fertilizer, ${ }^{36}$ where an employer locked out employees until they unconditionally accepted the final wage offer and after six weeks ended the lock-out and dismissed the employees finally and irrevocably, the dismissal was held to be unfair since it lacked the important element of being coupled with an offer of re-instatement and also did not have the purpose of compelling the employees to accept the final wage offer of the employer.

Moreover, in National Union of Metalworkers of South Africa $v$ Aerial King Sales (Pty) $L t d,{ }^{37}$ where the employer had dismissed employees for refusing his final wage offer, the prohibition of final dismissals within the context of collective bargaining was emphasized this way:

"There is, however, nothing in the Act that suggests that paragraph (c) of the definition of a lock-out permits an employer to use the lock-out weapon to achieve a valid final dismissal of its employees. To dismiss employees

\footnotetext{
S 65(d)(i)-(ii).

199011 ILJ 338 (IC).

199011 ILJ 162 (IC).

Supra $165 \mathrm{I}$.

199112 ILJ 822 (IC).

199415 ILJ 1384 (IC).
} 
because they do not want to accept management's final offer on wages cannot constitute a valid reason for dismissal.

In conclusion, under the Labour Relations Act 28 of 1956, dismissal, provided that it was conditional, was accepted as a legitimate instrument of coercion in the collective bargaining process. Employers were permitted to make use of dismissal as a way of compelling employees to agree to demands or proposals concerning terms or conditions of employment. However, such dismissals were subject to the fact that they had to be coupled with an offer of re-employment upon the employees' acceptance of the demands of the employer. Dismissals emanating from the context of proposing changes to terms and conditions of employment, and not subject to being withdrawn upon employees' acceptance of the employer's demand, fell outside the ambit of the lock-out since they were final and irrevocable. Such dismissals were held to be unlawful. ${ }^{39}$

\section{The Labour Relations Act 66 of 1995}

\section{Section 213 and the definition of a lock-out}

The Labour Relations Act 66 of 1995 also permits the employer to use the lock-out option as a way of enforcing his demands in the process of collective bargaining. The Act states explicitly that "every employer has recourse to lockout". ${ }^{40}$ The Labour Relations Act of 1998 defines a lock-out as:

"the exclusion by an employer of employees from the employer's workplace, for the purpose of compelling the employees to accept a demand in respect of any matter of mutual interest between employer and employee, whether or not the employer breaches those employees' contracts of employment in the course of or for the purpose of that exclusion".

From this definition it is clear that unlike the 1956 Labour Relations Act where the definition of a lock-out made provision for an employer to dismiss employees as a way of compelling them to accept a demand concerning terms and conditions of employment, such a dismissal is not catered for. In terms of this Act the termination of employees' contracts, whether conditional or final, as a way of inducing compliance with the employer's demands is not permissible within the context of collective bargaining.

An employer, in terms of this definition, may only exclude the employees physically as a way of compelling them to accept his demands in any matter of mutual interest but not dismiss them. This may be seen in the light of the fact that one of the primary objects of the 1995 Labour Relations Act is to promote orderly collective bargaining. ${ }^{42}$ Allowing employers the right to dismiss, even if it is a conditional dismissal, would disrupt the balance of

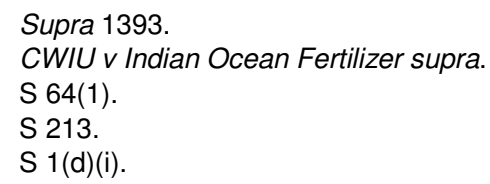


forces in the collective bargaining process, thereby undermining one of the primary objects of the Labour Relations Act.

It could also be said that this is indicative of the intention not to weaken or prejudice the employees' position during the collective bargaining process, through, for instance, permitting the employer to resort to dismissal in the collective bargaining process when there is a deadlock.

\section{Section 187(1)(c)}

Section 187(1)(c) reads as follows:

"(1) A dismissal is automatically unfair if the employer, in dismissing the employee, acts contrary to section 5 , or, if the reason is -

(c) to compel the employee to accept a demand in respect of any matter of mutual interest between the employer and employee."

This section categorically states that a dismissal that is intended to compel the employee to accept a demand in respect of any matter of mutual interest between the employer and the employee is automatically unfair. This means that during the collective bargaining process an employer is strictly prohibited from resorting to dismissing employees as a way of compelling them to agree to his demands, even if the dismissal is conditional. This could be interpreted as an appreciation of the fact that the employer-employee relationship is characterized by inherent inequality. If an employer could be allowed to dismiss employees during the collective bargaining process, not only would the employees' bargaining position be greatly prejudiced but one of the primary objects of the Labour Relations Act of 1995 which is to promote orderly collective bargaining, ${ }^{44}$ would also be undermined. Such a situation would render the very essence of collective bargaining meaningless as the employer would be allowed to raise the threat of a dismissal, which is more harsh to employees in terms of effects than any other mechanism in the collective bargaining, should employees be unwilling to accept his demands.

Also, the International Labour Organisation states that:

"collective bargaining, if it is to be effective, must assume a voluntary quality and not entail recourse to measures of compulsion which would alter the voluntary nature of such bargaining".

This indicates that measures like dismissal which would amount to some form of compulsion which would fundamentally alter the voluntary nature of collective bargaining are not permissible in the collective bargaining process. Permitting employers to resort to such measures would threaten the fundamental nature of collective bargaining.

\footnotetext{
S 187(1)(c) of the 1995 Labour Relations Act.

$\mathrm{S} 1$ (d)(i).

45 "On Freedom of Association" 1996 Freedom of Association Digest 9.
} 
In essence, section $187(1)$ (c) was aimed at categorically doing away with the dismissal lock-out which employers could resort to under the Labour Relations Act of 1956. The fact that such a dismissal was placed in the category of not just an ordinary unfair dismissal but an automatically unfair dismissal which incurs harsher sanctions is indicative of the intention of completely doing away with the dismissal lock-out, and an attempt not only to safeguard the sanctity of collective bargaining jealously where dismissals in relation to disputes concerning matters of mutual interest are not allowed, but to provide protection to the employees' bargaining power through ensuring the use of power-play tactics like strikes and lock-outs and not dismissal during the collective bargaining process. Placing a dismissal that is intended to compel employees to accept a demand in respect of any matter of mutual interest within the category of unfair dismissals was intended to ensure that an employer who effected such a dismissal would suffer serious consequences.

\section{Sanctions that emanate from section 187(1)(c)}

A dismissal that is automatically unfair incurs harsh consequences for the employer. The importance of judging the seriousness of sanctions when dealing with automatically unfair dismissals was highlighted by Nicholson JA in CEPPWAWU v Glass \& Aluminium $2000 \mathrm{CC}^{46}$ in this way:

"The reasons listed in $s$ 187(1)(a)-(f) include dismissals motivated by unfair discrimination against an employee directly or indirectly, or any arbitrary ground, including race, gender, sex, colour, conscience, belief, political opinion, and others. A dismissal of an employee for any one of those reasons strikes at the essence of the values which form the foundations of our new democratic society as enunciated in the Constitution. It is a dismissal that undermines the fundamental values that the labour relations community in our country depends on to regulate its very existence. Accordingly, such a dismissal deserves to be dealt with in a manner that gives due weight to the seriousness of the unfairness to which the employee was subjected"' (authors' emphasis).

This means that a dismissal that is found to have been effected for the purpose of compelling an employee to accept a demand in respect of any matter of mutual interest (thereby falling within the category of automatically unfair dismissals) will incur a very harsh sanction. In terms of the Labour Relations Act of 1995 an automatically unfair dismissal may incur a penalty of reinstatement, re-employment and compensation. ${ }^{48}$

Moreover, the Labour Court may also in addition make any other order that it considers appropriate in the circumstances. ${ }^{49}$ Concerning compensation, an employer may be ordered to pay compensation the maximum of which may be 24 months. ${ }^{50}$

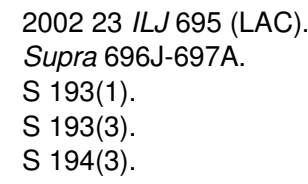


In conclusion, the fact that a dismissal which is intended to compel an employee to accept a demand in any matter of mutual interest has been placed within the section of automatically unfair dismissals that incur harsh sanctions indicates the intention to proscribe such dismissals effectively, irrespective of whether the dismissal is conditional or not. This also signals clearly an unequivocal intention to do away with the termination lock-out.

\section{The tension between section 187(1)(c) and section 188(1)(a)(ii) of the Labour Relations Act 66 of 1995}

\section{Section 187(1)(c)}

Section $187(1)$ (c) of the Labour Relations Act states categorically that a dismissal that is aimed at compelling an employee to accept a demand in respect of any matter of mutual interest is automatically unfair. This means that within the context of introducing changes to terms and conditions of employment an employer is prohibited from resorting to dismissals. An employer may have a pressing need to introduce changes to the terms and conditions of employment of his employees in order to run his enterprise efficiently, and the employees may be unwilling to accept such changes. This could, for instance, include changes in the shift system and working hours. This would put the employee in an untenable position of running the enterprise inefficiently since the employees would be rejecting the proposed changes aimed at bringing about efficiency. This would obviously be not adding any value to functional collective bargaining. In that case, the employer can make use of negotiations or the lock-out, for instance, to induce employees to comply with his demands, but he cannot resort to dismissing the employees. This principle was emphasized by Landman $\mathrm{J}$ in Schoeman $v$ Samsung Electronics (Pty) Ltd in this way:

"An employer in the private sector needs to be able to survive and prosper economically. To do this the employer must meet changed market circumstances and be competitive. To meet the changes of the market adaptations are required. An employer needs the flexibility to deploy, reasonably quickly and efficiently, the resources at the employer's disposal. Various options are open to an employer to achieve this. One of them is the lock-out route which is used to compel acceptance of a demand ... An employer may not dismiss employees in order to compel acceptance of a demand" ${ }^{\prime 51}$ (authors' emphasis).

The employer is precluded from dismissing the employees in order to compel them to accept his demands. In this way the process of collective bargaining ensures that when employees are involved in negotiations with the employer, they are protected from being threatened with dismissal by the employer, should they not agree to accede to his demands. If an employer dismisses the employees, even if the dismissal is conditional and subject to being withdrawn should the employees accept the demands of the employer,

51 Supra par 18 and 19. 
such a dismissal will be automatically unfair and will incur harsh sanctions for the employer.

\section{Section 188(1)(a)(ii)}

Section 188(1)(a)(ii) reads as follows:

"(1) A dismissal that is not automatically unfair, is unfair if the employer fails to prove -

(a) that the reason is a fair reason - ...

(ii) based on the employer's operational requirements ..."52

This section accords the employer the right to dismiss for operational requirements. For operational requirements dismissals to be substantively and procedurally fair, an employer has to comply with the procedures laid out in section 189 of the 1995 Labour Relations Act.

Matters like proposed changes to terms and conditions of employment traditionally fall within the ambit of mutual interest and disputes that arise from such matters are normally resolved through collective bargaining where dismissal is strictly prohibited. However, the very same matters can overlap and fall within the sphere of operational requirements and effectively become disputes of rights where an employer is legitimately allowed to resort to dismissal provided that a fair procedure, as laid out in section 189, is followed. This means that even in issues relating to matters of mutual interest where for instance an employer wants to introduce changes to the employees' terms and conditions of employment by changing working shifts, a matter which under normal circumstances, would fall within the ambit of collective bargaining where dismissal is forbidden, the employer may legally be entitled to dismiss those employees not because he is compelling the employees to accept his demands but on the grounds that such change is necessitated by operational requirements and he wants to replace those employees with those willing to work under those terms.

One of the unfortunate unintended consequences of this section is that it has the potential to convert through manipulation what may be an interest dispute that should be resolved through collective bargaining, and without using dismissal as a measure of compulsion into a rights dispute where dismissal may be resorted to by the employer under the guise of operational requirements.

This section also has the potential to undermine the process of collective bargaining as well as the intention of the Labour Relations Act to prohibit the use of dismissal in compelling acceptance of a demand relating to matters of mutual interest. ${ }^{53}$ This paradox was highlighted in Schoeman $v$ Samsung Electronics (Pty) Ltd, when Landman J stated that:

\footnotetext{
S 188(1)(a)(ii).

$S$ 187(1)(c).
} 
"An employer may not dismiss employees in order to compel acceptance of a demand but this does not prevent the employer resorting to dismissal for operational requirements in a genuine case.

In short, whilst an employer is precluded from using dismissal as a way of inducing employees to accept a demand in respect of any matter of mutual interest, there is nothing that prohibits an employer from dismissing employees who refuse to accept changes to their terms and conditions of employment if he can show that the mooted changes are necessitated by operational requirements. The hurdle that he would then have to clear is to follow the conditions stipulated in section 189 of the Labour Relations Act of 1995.

\section{The tension between section 187(1)(c) and section 188(1)(a)(ii)}

Whilst the express intention of section 187(1)(c) was to do away with the dismissal lock-out completely, which was permissible under the 1956 Labour Relations $\mathrm{Act}^{55}$ and according to which an employer could use dismissal as way of forcing the employees to capitulate to his demands relating to employees' terms and conditions of employment, it is its practical application that has created more problems than solutions, particularly when viewed against section 188(1)(a)(ii).

Section 187(1)(c) effectively prohibits dismissals as an instrument of coercing an employee to accept a demand in respect of any matter of mutual interest between the employer and the employee. However, matters of mutual interest can also generally include matters that are the subject of terms and conditions of employment. These would for example include issues like wages, work shifts and leave. If an employer proposes changes related to some of these issues and the employees do not accept the changes, the employer would be precluded from dismissing those employees. Such a dismissal would be automatically unfair. The intention behind this was to ensure that an employer does not evade the collective bargaining process by manipulating a dispute of interest and converting it to a right dispute through resorting to dismissal.

However, if the employer can, for instance, propose changes relating to work shifts and argue that the change in work shift is necessitated by operational requirements he can rely on section 188(1)(a)(ii) which permits dismissal on the grounds of operational requirements. The employer would argue that the employees are not dismissed as a way of compelling them to accept the demands or changes but they are dismissed because those changes are necessary for the operational requirements of the business and the employer wants to replace those employees with employees who are willing to work under the new changes.

\footnotetext{
Supra par 19

S 1 (d).
} 
This provides a fertile ground for a situation where an unscrupulous employer, fully knowing that options like negotiations and lock-outs, may not elicit a positive response to a proposal immediately to effect changes to terms and conditions of employment, may from the outset during negotiations raise the "spectre" of dismissals for operational requirements as a way of exerting pressure on employees to agree to his demand. In essence, this creates a situation where an interest dispute, where dismissal is prohibited, can easily migrate into a rights dispute where dismissal is permissible. The unfortunate part of this is that it is quite difficult to differentiate clearly whether a dismissal relating to proposals for change to the terms and conditions of employment is motivated by a desire to compel employees to accept an employer's demand or is genuinely precipitated by operational requirements. This is because in both instances, proposed changes to terms and conditions of employment play a central role.

It is against this background that Cheadle et al posed this rhetorical question:

"An employee may no longer dismiss employees to compel them to accept new terms and conditions of employment. But how different is that from dismissing an employee on the grounds of operational requirements because the employer needs to change a term or condition of employment and the employee refuses to agree to it?

The fact that an employer may not dismiss an employee as a way of compelling him to accept a demand in respect of any matter of mutual interest, but at the same time can still manœuvre his way out of this prohibition by raising the defence of operational requirements and still dismiss employees who are unwilling to accept the demand, poses serious challenges for the collective bargaining process.

The problem stems mainly from the fact that the term "operational requirements" is broadly defined in the 1995 Labour Relations Act. "Operational requirements" refers to requirements based on the economic, technological, structural or similar needs of an employer. ${ }^{57}$ This broad definition permits proposed changes to terms and conditions of employment, normally classified as matters of mutual interest which are resolved through collective bargaining to fit comfortably within the sphere of disputes of right also. The key issue is where to draw the line at which a dispute of interest should move away from being strictly resolved through the process of collective bargaining to the arena of a dispute of right where dismissal is permissible. How to distinguish a dismissal, within the context of proposed changes to terms and conditions of employment, that is aimed at compelling employees to accept a demand in respect of a matter of mutual interest from a dismissal that emanates from the same proposed changes to terms and conditions of employment, but based on genuine operational requirements, is the challenge. 
This is the problem that confronted the court in SA Chemical Workers Union $v$ Afrox $L t d^{58}$ and where Landman $\mathrm{J}$ held that the solution, which by his own admission was not the most satisfactory one, would be to look at the reason behind the dismissal and whether the procedures specified in section 189 of the 1995 Labour Relations Act have been complied with when effecting the dismissal. If the procedures have not been complied with, then the dismissal could be regarded as having been aimed at compelling employees to accept a demand in respect of a matter of mutual interest and therefore unlawful.

Cheadle et $a^{59}$ rejected this approach and argued that if the reason behind the dismissal is to compel the employee to accept new terms and conditions of employment and is regarded as being automatically unfair, then complying with section 189 cannot transform it into a fair one. $\mathrm{He}$ argued instead that the phrase "operational requirements", when applied in the context of changes to terms and conditions of employment, should be interpreted strictly and only refer to redundancy and not to situations where an employer, for instance, seeks to replace existing employees with shortterm or contract workers.

This notion of a restrictive application was further stressed by Thompson ${ }^{60}$ who also suggested that the phrase within the context of changes to terms and conditions of employment should be applied only to retrenchments that emanate from a situation where the survival of the business is under threat and not to situations where the employer seeks to make profits.

However, the courts have emphatically rejected this restrictive approach in Fry's Metals $v$ NUMSA ${ }^{61}$ on the basis that there is no statutory basis for such an argument. This rejection, based on the assertion that there is a distinction between a dismissal that is based on operational requirements and one that is aimed at compelling employees to accept a demand in respect of a matter of mutual interest, has resulted in some rather unfair situations. The distinction, being that as long as a dismissal is permanent, it does not fall within section 187(1)(c), has resulted in a rather absurd situation where two dismissal cases revolving around proposed changes to terms and conditions, working shifts systems to be specific, were in fact decided differently. In Fry's Metals $v$ NUMSA, ${ }^{62}$ where the employer indicated that the dismissals were final, the court held that the dismissals were fair. On the other hand, in Chemical Workers Union v Algorax (Pty) $L_{t d}{ }^{63}$ the employer coupled the dismissal with an offer of re-employment and this led the court to rule that the dismissal was automatically unfair since it was not final and irrevocable.

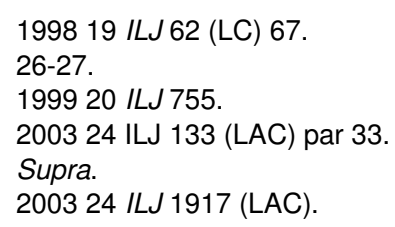


The fact that the line between an automatically unfair dismissal for compelling employees refusing to accept changed terms and conditions of employment and a legitimate dismissal on the grounds of an employer's operational requirements is often a fine one that creates a problem. An employer who couches a dismissal in the wrong way, legally speaking, by showing some form of generosity through offering reinstatement can incur serious sanctions whilst the one who shows no mercy by terminating the employment relationship permanently may incur less serious sanctions, or no sanction whatsoever. Van Niekerk ${ }^{64}$ captures the absurdity of this situation in this way:

"If the employer intends finally to terminate the employment relationship by dismissing its workforce and to employ a new workforce on the terms rejected by those dismissed, there is no automatically unfair dismissal. If the dismissal is effected with a more equivocal intention, the employer is at risk of an automatically unfair dismissal."

It is for this reason that Van Niekerk ${ }^{65}$ expresses his opinion concerning the way the courts have interpreted section $187(1)(c)$ in this way:

"This is probably the most controversial of the automatically unfair reasons for dismissal. The ambit of the provision is ambiguous and its consequences are capacious."

In short, the tension between the two sections can give rise to an absurd situation where two employers who may dismiss employees who refuse to accept changes to their terms and conditions incurring different sanctions depending on the label that they attach to the dismissal. It may also result in a situation where an employer may circumvent the process of collective bargaining by raising the shield of "operational requirements" and using dismissal when unable to secure the consent of the affected employees. This would greatly undermine the collective bargaining process. It is against this background that Thompson ${ }^{66}$ argues:

"when parties are engaged in economic bargaining, one of them should not be allowed to pull the plug on the process by threatening the demise of the other if it does not get its way. The courts should look especially critically at the claim that a fair reason relating to the operational requirements of a business permits an employer engaged in bargaining to throw the dismissal lever if its entire package is not accepted. The reason for this should be obvious: it is an expedient open to abuse, and its ready availability would undermine the institution of collective bargaining, the bearer of so many key aspirations of the Labour Relations Act (LRA).'

64 Van Niekerk and Linstrom Unfair Dismissal 3ed (2006) 36.

65 Van Niekerk and Linstrom 37.

66 "Bargaining over Business Imperatives: The Music of the Spheres after Fry's Metals" 2006 27 ILJ 704.

67 Thompson 200627 ILJ 710. 


\section{CASE LAW PERTAINING TO DISMISSALS WITHIN THE CONTEXT OF PROPOSED CHANGES TO TERMS AND CONDITIONS OF EMPLOYMENT}

\section{Background}

Section $187(1)(c)$ renders dismissal within the context of a lock-out unfair. The great difficulty concerning this section is its practical application when it comes to proposed changes relating to terms and conditions of employment. Whilst this section prohibits dismissal of employees for refusing to accept a demand of an employer in respect of a matter of mutual interest, an employer is permitted to dismiss employees on the grounds of genuine operational requirements. $^{68}$

Proposed changes to terms and conditions of employment fall within the sphere of mutual interest which are normally resolved through collective bargaining using power play tactics like lock-outs. However, the very same proposed changes to terms and conditions of employment fall within the category of operational requirements which are classified as dispute of rights where an employer is permitted to retrench or dismiss. This results in a situation where the demarcation of the routes that are followed for rights and interest disputes becomes blurred. This paradoxical situation was captured by Cohen in this way:

"Interest disputes are intended to be resolved in the collective bargaining arena. Allowing an employer to undermine this process by unilaterally exercising the power to dismiss in order to compel an employee to accept a demand, would be in breach of $s$ 187(1)(c) and would constitute an automatically unfair dismissal. Nevertheless, the wide scope of 'mutual interest' disputes encompasses proposed changes to terms and conditions of employment as part of a business restructuring exercise.

Notwithstanding the clear demarcation of interest and rights disputes and their respective dispute-resolution forums, such disputes by their very nature fall within the ambit of $s 189$.

The challenge that has faced the courts when dealing with dismissals that arise from the context of proposed changes to terms and conditions of employment is to determine the point at which an employer's desire to introduce changes through resorting to dismissal moves away from being an attempt to compel employees to accept a demand in respect of a matter of mutual interest to being a genuine and fair dismissal justifiable on operational grounds.

According to $\mathrm{Du}$ Toit et al $^{70}$ the challenge that faces the courts in this regard can be summed up as follows:

\footnotetext{
S 188(1)(a)(ii).

69 "Dismissals to Enforce Changes to Terms and Conditions of Employment - Automatically Unfair or Operationally Justifiable" 200425 ILJ 1883.

70 Du Toit, Bosch, Woolfrey, Godfrey, Cooper, Giles, Bosch and Rossouw Labour Relations Law 5ed (2006) 390.
} 
"The question that has confronted the courts is whether section 187(1)(c) should be narrowly interpreted as applying only to dismissals that are truly designed to make employees change their minds in a dispute with an employer on matters of mutual interest - in other words, dismissals that are conditional in the sense that they will be reversed if the employees accept the employer's demand - or whether it should also apply to the unconditional dismissal of employees who reject an employer's demand in a matter of mutual interest."

This is the point at which the Labour and the Labour Appeal Courts have differed greatly. The Labour Court, on quite a number of instances, held that the prohibition of dismissal as a way of compelling employees to accept a demand in respect of a matter of mutual interest applies to both conditional and unconditional dismissals. ${ }^{72}$ On the other hand, the Labour Appeal Court has held that the prohibition on dismissal only applies to conditional dismissals. ${ }^{73}$

\section{The Labour Court}

When confronted with a dispute over dismissals where employees refused to accept changes to terms and conditions of employment, the Labour Court was quick to classify the dismissals as emanating from the collective bargaining process where dismissal is not a legitimate instrument of exerting pressure on employees. Consequently such dismissals were held to fall squarely within the ambit of section $187(1)(\mathrm{c})$, thereby rendering them automatically unfair. The court made it clear that the employer should have made use of options like a like lock-out instead of dismissal.

\section{NUMSA v Fry's Metals (Pty) Ltd}

In National Union of Metalworkers of South Africa $v$ Fry's Metals ${ }^{74}$ the employer wanted to introduce a new shift system and also to do away with transport subsidy. Upon failing to persuade the employees to accept the proposed change in the shift system, the company wanted to retrench the employees on the grounds of operational requirements. The union on the other hand, contended that the dismissals were mainly aimed at compelling the employees to accept the employer's demand and therefore automatically unfair.

Firstly, the court classified the dispute about the proposed change in the shift system as a classical mutual interest dispute that is resolved through the collective bargaining process where dismissal is not permitted. The court also emphasized that by resorting to dismissing the employees who refused to agree to its demands, the employer had attempted to avoid using

\footnotetext{
Ibid.

72 National Union of Metalworkers of South Africa v Fry's Metals (Pty) Ltd 200122 ILJ 701 (LC).

73 Fry's Metals v National Union of Metalworkers of South Africa of South Africa 200324 ILJ 133 (LAC).

74200122 ILJ 701 (LC).
} 
legitimate collective bargaining mechanisms like conciliation and lock-out. When ruling that the employer had wrongly used dismissal within the context of collective bargaining the court remarked:

"Dismissal is not a legitimate instrument of coercion in the collective bargaining process. The change in the definition of a lock-out means that even the temporary and tactical dismissal is precluded. Section 187(1)(c) renders any dismissal to compel acceptance of an employment demand automatically unfair, ... Wage-work deals must be the products of methods stopping short of the dismissal spectre"75 (authors' emphasis).

It can therefore be deduced that the use of the phrase "any dismissal" is indicative of the fact that from the court's perspective, any dismissal that is meant to compel employees to accept a demand, whether conditional or unconditional falls squarely within the ambit of section 187(1)(c).

Moreover, the court held that the employer had used the threat of dismissing the employees when it reached the point of impasse in the negotiations about the proposed change in the shift system. Prior to reaching the impasse, the employer had made no intention of its desire to dismiss the employees. It was clear then, the court held, that the employer had used the threat of dismissal as a "negative inducement to employees to abandon their reluctance to accept the new shift system". ${ }^{76}$

The court, by holding that the dispute and the subsequent negotiations about the proposed change in the shift system fell within the "wage-work bargain", where dismissal is not permissible, endorsed Thompson's ${ }^{77}$ view that such disputes "not be allowed to escape the protected zone of collective bargaining". Most importantly, the court commented that allowing employers to resort to dismissals within the context of collective bargaining, thereby avoiding other mechanisms acceptable in the collective bargaining process, would be tantamount to undermining one of the primary objects of the 1995 Labour Relations Act, namely to promote orderly collective bargaining. ${ }^{78}$

\section{NUMSA v Zeuna-Starker Bop (Pty) Ltd}

In National Union of Metalworkers of South Africa v Zeuna-Starker Bop (Pty) $L t d^{79}$ the employer dismissed employees after they had rejected its final wage offer, citing operational requirements as the reason. Interestingly, the employer first embarked on the lock-out route, a weapon fully acceptable in the collective bargaining process but later abandoned it and resorted to dismissing the employees who rejected its final wage offer.

The court ruled that the company was not justified to use dismissal as a way of compelling employees to accept its wage offer. The dispute was a dispute of interest in respect of a matter of mutual interest between the

National Union of Metalworkers of South Africa v Fry's Metals supra par 38.

Supra par 51.

199920 ILJ 755-766.

National Union of Metalworkers of South Africa v Fry's Metals (Pty) Ltd supra par 59.4.

200223 ILJ 2283 (LC). 
employer and the employees. It had to be resolved within the domain of collective bargaining where weapons like a lock-out are permissible, and not dismissal.

One of the interesting dimensions of the dispute was that in the notice of retrenchment, the employer made it clear that it would re-employ the employees if they accepted its wage offer. Therefore, the dismissals were conditional and aimed at compelling the employees to accept the employer's demand. Consequently, the dismissal fell within section 187(1)(c) and was therefore automatically unfair.

Having declared the dismissal unfair, the court ordered the re-instatement of the dismissed employees even though it acknowledged that the reinstatement would lead to retrenchment of other permanent employees. ${ }^{80} \mathrm{In}$ line with the sentiment expressed in CEPPWAWU $v$ Glass \& Aluminium $2000 C C^{81}$ that an automatically unfair dismissal has to be dealt with in a manner that "gives due weight to its seriousness", the court ordered reinstatement dating back to 43 months and compensation up to 24 months.

\section{NCBAWU v Hernic Premier Refractories (Pty) Ltd}

In National Construction Building \& Allied Workers Union v Hernic Premier Refractories (Pty) $L t d^{82}$ the employer proposed changes to terms and conditions of employment as a way of restructuring its business. After failing to secure acceptance of its proposed changes it embarked on a retrenchment exercise on the grounds of operational requirements.

The court held that the dispute was one that fell within the dispute of interest domain which had to be resolved through collective bargaining by using mechanisms like negotiations. The court reiterated the notion expressed in NUMSA $v$ Fry's Metals ${ }^{83}$ that dismissal is not a legitimate weapon for compelling employees to accept an employer's demand in a matter of mutual interest. Interestingly, whilst acknowledging that the employer was experiencing financial losses amounting to approximately R4 000000 per month (therefore having a valid operational requirement reason to retrench), the court still found that the dismissal was motivated by a desire to compel employees to accept the employer's demand. ${ }^{84}$ This shows that the mere presence of a valid operational reason for dismissal does not automatically mean that the dismissal falls outside the scope of section $187(1)(c)$.

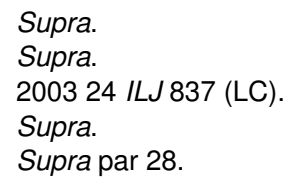




\section{FAWU v General Food Industries Ltd}

In Food \& Allied Workers Union v General Food Industries Ltd ${ }^{85}$ the court had to deal with a situation where the employer, after having concluded a wage increase (albeit under duress and for fear of a strike action) with a union, embarked on a retrenchment exercise a month later. The question that the court had to address was whether an employer could use retrenchment or outsourcing to achieve what it had failed to attain through the collective bargaining process, namely to reduce or freeze the proposed wage increase. Also, the court had to consider a situation of where a dispute of interest in the form of a dispute about wage increase had moved away from the protected zone of collective bargaining where dismissal is precluded to the zone of disputes of right where dismissal is permissible.

In addressing these questions the court first acknowledged that the demarcation line between interest disputes and rights dispute is not always clear-cut, particularly when a dispute has moved away from the zone of collective bargaining where power-play is the norm to the sphere of disputes of rights dispute. In this case the dispute had shifted from being a dispute about wage increase to whether it was permissible for the employer to embark on outsourcing as a way of undoing the effects of the wage agreement that it had concluded under duress, mainly because of the fear of industrial action. This had resulted in a situation where there was some kind of an overlapping of issues. The court explained this overlapping in this way:

"When however the court is confronted with a situation where it is alleged that
an interest (i.e. non-legal claim) dispute has migrated from the protected
collective bargaining zone to the rights or justiciable (legally based claim)
zone by a process of manipulation, then the solutions or answers become less
clear-cut. Although the definitions of 'rights' (which concerns a legal claim)
and 'interest' (a claim for something new) disputes are fairly well-established),
it is sometimes not easy to apply them to the facts of a particular case. This is
such a case.".86

Basing its argument on Thompson's, ${ }^{87}$ that in disputes that are "purely over the wage bargain" dismissal should not be permitted, the court ruled that since the dispute revolved around a wage increase which the company had consented to through a collective agreement, the dispute was a "classic interest dispute" and dismissal was not permissible. Whilst acknowledging that the company had a right to embark on outsourcing, the court held that in this case the company had used outsourcing as a tool to undermine the collective bargaining process through which the collective agreement on the six per cent increase had been concluded. Making short shrift of the company's argument that it had concluded the wage increase agreement, which it claimed was not affordable, under pressure and for fear of industrial action, the court argued as follows:

200223 ILJ 1808 (LC).

Supra par 13

199920 ILJ 755-756. 
"The company was frustrated by the 'inherited' centralized bargaining structure, but participated fully and actively in the collective bargaining process. An outcome was agreed, albeit under threat of industrial action. That is the very essence of collective bargaining - the use of power to extract a favourable outcome" ${ }^{\text {"88 }}$ (authors' emphasis).

Most importantly, in a serious effort to preserve the sanctity of collective bargaining and discourage the practice of parties first attempting to resolve disputes through the collective bargaining process, and upon failing to achieve a desired outcome, then resorting to tactics like dismissal, the court emphatically stated that such a situation should be vigorously discouraged. The court asserted:

"When a party elects to resolve a dispute by adopting a particular (collective bargaining) route, this court must hold that party to the bargain unless that party can show that a deviation is justified by exceptional circumstances."

Unsurprisingly, the court held that the dismissals were primarily meant to undermine the collective agreement on the wage increase. The company had decided to use outsourcing as a ploy to obtain the reduction in wages that it had failed to achieve in the collective bargaining process. The court held:

"In this case, the company used outsourcing as a device for undermining the status of the wage agreement concluded on 14 October 1999), and as a device for undermining the status of the union as the exclusive recognized collective bargaining agent of the dismissed employees."

Consequently, the dismissals were held to be automatically unfair as they fell within the ambit of section 187(1)(c).

\section{A critical analysis of the Labour Court's approach}

From the cases discussed, it appears that when confronted with a dismissal emanating from the collective bargaining context, the Labour Court was guided by one of the primary objects of the Labour Relations Act 66 of 1995, namely to promote orderly collective bargaining. ${ }^{91}$ The decisions of the court were meant to ensure that the sanctity of the collective bargaining process was preserved through ensuring that employers are precluded from resorting to dismissal upon failing to secure a desired outcome in the process of negotiations. The court's intention seems to prevent a situation whereupon reaching an impasse in the negotiation process, the employers could easily resort to dismissal or better still, retrenchment, under the guise of operational requirements, whilst in actual fact the main intention was to compel employees to accept a demand in a matter of mutual interest.

\footnotetext{
Supra par 29.

Supra par 31.

Supra par 37.

S 1 (d)(i).
} 
Firstly, the Labour Court paid particular attention to the dichotomy of dispute of interest and dispute of right and the route that each dispute was supposed to follow. Upon identifying the nature of the dispute, the court then outlined the route that the dispute had to follow. Admittedly, there are situations where this dichotomy of disputes of rights and dispute of interest becomes blurred. This the court did acknowledge in Food \& Allied Workers Union $v$ General Food Industries. ${ }^{92}$ However, this did not distract the court from classifying the dispute in an appropriate way and consequently prescribing the correct route to be followed in resolving the dispute in that particular case.

Secondly, the court also adopted a purposive approach in interpreting section 187(1)(c). The court interpreted the section to apply to all dismissals (whether conditional ie subject to being withdrawn upon acceptance of an employer's demand or unconditional) that arose from the collective bargaining context or, to be specific, from proposed changes to terms and conditions of employment. This was categorically stated in NUMSA v Fry's Metals, where the court held that:

"Section $187(1)(\mathrm{c})$ renders any dismissal to compel acceptance of an
employment demand automatically unfair, ..."

Whether an employer claimed that a dismissal was necessitated by operational requirements and not aimed at compelling an employee to accept a demand, the court scrutinized the nature of the dispute to ascertain whether it arose from the sphere of matters of mutual interest, where dismissal is prohibited.

Moreover, in National Construction Building \& Allied Workers Union v Hernic Premier Refractories ${ }^{94}$ the court made a very important observation that in a dismissal case, the mere existence of a valid operational reason does not guarantee a dismissal immunity from section 187(1)(c) or being found to be automatically unfair. This observation was later on echoed by the Labour Appeal Court in Chemical Workers Industrial Union v Algorax (Pty) $L t d^{95}$

Most importantly, in Food \& Allied Workers Union $v$ General Food Industries ${ }^{96}$ the court emphasized the principle that parties engaged in the collective bargaining process should not be allowed to manipulate the process by opting to move out of it through characterizing a dispute as a dispute of right instead of a dispute of interest when the going gets tough. This would prevent a situation where an employer would first embark on negotiations about introducing changes to terms and conditions of employment and, upon the negotiations reaching an impasse, the employer would raise the spectre of dismissal on operational grounds as a way of exerting pressure on employees instead of using accepted collective

\footnotetext{
Supra par 13.

Supra par 38.

Supra.

Supra.
}

96 Supra. 
bargaining mechanisms like a lock-out. The court emphasized this principle in this way:

"When a party elects to resolve a dispute by adopting a particular (collective bargaining) route, this court must hold that party to the bargain, unless that party can show that a deviation is justified by exceptional circumstances."

In conclusion, the Labour Court in its decisions sought to protect employees from being dismissed in disputes that arose from the context of proposed changes to the terms and conditions of employment. The court also prevented the employers from using dismissal under the guise of retrenchment as a subtle way of compelling employees to accept an employer's demand in respect of matters of mutual interest. It restored the sanctity of the collective bargaining process through outlawing dismissals in the process, and instead emphasizing the importance of using acceptable mechanisms of power-play like negotiations and the lock-out. In essence, it protected employees against being bullied by employers through using threats of dismissal as a way of inducing agreement in the collective bargaining process. In this way, the court gave effect to the express intention of section 187(1)(c), namely to do away with the dismissal lock-out. Most importantly, in Food \& Allied Workers Union v General Food Industries ${ }^{98}$ the court sought to prevent a situation where an employer could dismiss employees for operational reasons after concluding an agreement that it considered unsustainable. Collective agreements are an essential element of the collective bargaining process. To allow employers to escape from collective agreements that they conclude on the grounds of operational requirements dismissal would undermine the very purpose of the collective bargaining process.

\section{THE KEY AUTHORITY}

\section{Fry's Metals (Pty) Ltd $v$ National Union of Metalworkers of South Africa}

The Labour Court's finding in NUMSA v Fry's Metals ${ }^{99}$ that section 187(1)(c) applies to all dismissals (whether conditional or unconditional) that arise from the context of proposed changes to terms and conditions of employment was rejected by the Labour Appeal Court. On appeal, the court in Fry's Metals (Pty) Ltd $v$ National Union of Metalworkers of South Africa ${ }^{100}$ clearly stated that section 187(1)(c) only applies to dismissals that are subject to being withdrawn by the employer upon the employees' acceptance of the employer's demand. A dismissal which is final and not subject to being withdrawn falls outside the ambit of the section. According to the court, a dismissal contemplated by section 187(1)(c) is temporary

\footnotetext{
Supra par 31.

Supra.

Supra.

200324 ILJ 133 (LAC).
} 
because it is subject to being withdrawn when employees accept the employer's demand because its main aim is not really to dismiss the employees but instead to induce them to comply with the employer's demand. On the other hand, a dismissal that is effected for operational requirements in terms of section 188(1)(a)(ii) is permanent and its intention is to replace workers who are not prepared to work under the terms and conditions of employment demanded by the operational requirements of the business with those willing to do so.

\section{The historical context of section 187(1)(c)}

In answering the question of whether an employer has a right to dismiss employees who refuse to accept changes to their terms and conditions of employment when such changes are necessary for the viability of the employer's enterprise and whether there is a link between such a dismissal and that contemplated by section 187(1)(c), Zondo JP first examined the historical background of section 187(1)(c).

He argued that section 187(1)(c) was intended to do away with the concept of a dismissal lock-out as encapsulated in the definition of a lock-out in terms of the 1956 Labour Relations Act. ${ }^{101}$ In terms of that definition of the lock-out an employer was permitted to dismiss employees as a way of inducing them to accept a demand. However, the dismissal had to be conditional and coupled with an offer of re-employment should the employees accept the demand. Such dismissals, for example in CWIU $v$ Indian Ocean Fertilizer ${ }^{102}$ were held to be fair.

Dismissals that were final and not accompanied by an offer of reemployment upon acceptance of employer's demand fell outside the ambit of the lock-out and were held to be unfair. Such was the case in Commercial Catering \& Allied Workers Union $v$ Game Discount World Ltd ${ }^{103}$ and National Union of Metalworkers of South Africa $v$ Aerial King Sales (Pty) Ltd. ${ }^{104}$

In essence section 187(1)(c) only seeks to outlaw conditional dismissals that have a purpose of compelling employees to accept a demand in respect of a matter of mutual interest. A dismissal that is unconditional falls outside the scope of this section. This was emphatically expressed this way:

"In order to fall within the ambit of $\mathrm{s} 187(1)$ (c) a dismissal must have as its purpose the compulsion of the employees concerned to accept a demand in respect of a matter of mutual interest between employer and employee."

To illustrate further that the section was mainly aimed at curbing conditional dismissal the court stressed that:

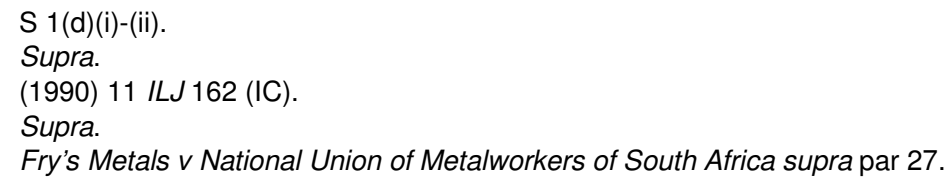


"A dismissal that is final cannot serve the purpose of compelling the dismissed employees to accept a demand in respect of a matter of mutual interest between employer and employee because, after he has been dismissed finally, no employment relationship remains between the two. An employee's acceptance of an employer's demand in respect of a matter of mutual interest can only be useful or worth anything if the employee is going to continue in the employer's employ. Let us say that an employer wants his employees to agree that a transport subsidy be done away with. If the employees accept this demand and continue in the employer's employ, that would serve a useful purpose. However, if the employees are dismissed finally and irrevocably, their agreement that the employer may do away with the transport subsidy is irrelevant. The people whose agreement matters are those who are going to be in his employ.

It is therefore clear that according to the court, section 187(1)(c) strictly applied to dismissals that are conditional and accompanied by an offer of reemployment upon acceptance of an employer's demand. Dismissals that are final in the sense that they are not accompanied by an offer of reemployment fall outside the scope of this section.

\section{The tension between section 187(1)(c) and section 188(1)(a)(ii)}

Having applied the literal approach of confining the interpretation of confining the meaning of section $187(1)$ (c) only to dismissals that are accompanied by an offer of re-employment, the court went on to hold that there was no tension between section 187(1)(c) and section 188(1)(a)(ii).

Basing its argument on the premise that a dismissal that falls within section 187(1)(c) is a dismissal that is conditional and subject to being withdrawn when the employees accept an employer's demand by virtue of the fact that its real purpose is not to dismiss them but to compel employees to accept an employer's demand, the court held that a dismissal that is based on operational requirements has a different purpose. Its purpose is to replace permanently the employees who are unwilling to work under the proposed changes to the terms and conditions which are necessary for the viability of an enterprise with employees who are willing to work under the changed terms and conditions of employment. This is what makes a dismissal that is intended to compel employees to accept a demand in respect of a matter of mutual interest different from that based on operational requirements. The court made this observation:

"I conclude that there is a distinction between a dismissal for a reason based on operational requirements and a dismissal the purpose of which is to compel an employee to accept a demand in respect of a matter of mutual interest between employer and employee. The distinction relates to whether the dismissal is effected in order to compel the employees to agree to the employer's demand which would result in the dismissal being withdrawn and the employees being retained if they accept the demand or whether it is effected finally so that, in a case such as this one, the employer may replace

106 Fry's Metals v National Union of Metalworkers of South Africa supra par 28. 
the employees permanently with employees who are prepared to work under the terms and conditions that meet the employer's requirements".

In short, the approach that the court adopted in relation to the apparent tension between the two sections was to overlook the fact completely that in both instances it is the employer's desire to effect changes to the terms and conditions of employment that eventually gives rise to the dismissal. For the court, the defining point is the purpose behind the dismissal. A dismissal as contemplated by section 187(1)(c) is accompanied by an offer of reinstatement if the employees accept an employer's demand and this indicates that the real intention of the employer is to induce acceptance of his demand. On the other hand, in a dismissal for operational requirements the dismissal is permanent and the aim is to replace the employees who are not prepared to work under the changed terms with those willing to do so.

The problem with this reasoning is that the line separating a dismissal that is intended to compel employees to accept a demand from that necessitated by operational requirements is a very fine one. Both have a link with matters of mutual interest, namely proposed changes to terms and conditions of employment which are normally resolved through collective bargaining and where dismissal is not permitted. Also, both emanate in essence from the refusal by employees to accept the proposed changes to their terms and conditions of employment. That this did not preoccupy the court is somewhat puzzling. All that the court preoccupied itself with was whether the dismissal was coupled with an offer of re-employment and if it did it fell within the ambit of section 187(1)(c) and was consequently automatically unfair.

\section{Rejection of Thompson's suggestion of not permitting "for profit" retrenchments}

Disputes about proposed changes to terms and conditions of employment fall within the sphere of matters of mutual interest. Matters of mutual interest give rise to disputes of rights which are normally resolved through collective bargaining. However, situations may arise where a dispute of interest may change and become a dispute of right. This was aptly stated in Food \& Allied Workers Union v General Food Industries Ltd (albeit in a strike context):

"That is not to say that a dispute of interest may not, for example, in the case of a strike, metamorphose into a dispute of rights. For example, when the economic survival of an enterprise is threatened by a strike, it may be justifiable to use retrenchment procedures."

This can also apply to the context of proposed changes to terms and conditions of employment. A dispute about the changes may start off as a matter of mutual interest and accordingly a dispute of interest but may overlap and fall within the domain of operational requirements thereby giving rise to disputes of right.

\footnotetext{
Fry's Metals v National Union of Metalworkers of South Africa supra par 31.

108 Suprapar 30.
} 
Thompson ${ }^{109}$ acknowledges the complex situation that disputes about proposed changes to terms and conditions have the potential to change from being a matter of mutual interest giving rise to dispute of interest issue to being a dispute of right issue. As a way of trying to resolve this predicament and reconciling the tension between section 187(1)(c) which forbids use of dismissal as a means of compelling employees to accept a demand in respect of a matter of mutual interest, and section 188(1)(a)(ii) which permits employers to dismiss an employee for operational reasons, he suggests that in cases directly linked to the collective bargaining process, where dismissal is prohibited, dismissals on operational grounds should only be allowed in limited circumstances.

In instances where the enterprise only intends making profits, dismissal on operational grounds should not be allowed because much as making profits is an operational reason it is not as compelling as in a situation where the very survival of a business is threatened. Such a dismissal should fall within section 187(1)(c). Dismissal should only be allowed in cases where the survival of the business is threatened. In essence, the suggestion was a means of protecting the sanctity of collective bargaining as a protected zone where dismissal is not permitted and only allowing resort to dismissal in exceptional cases such as when the very survival of a business is threatened.

Unfortunately, this view of confining operational requirements dismissals in the context of proposed changes to terms and conditions of employment was rejected by the court as having no statutory basis because the Labour Relations Act of 1995 does not distinguish between an employer's right to dismiss for a reason based on operational requirements "in the context of a business" the survival of which is under threat and a business which is making profit and wants to make more profit. ${ }^{110}$

The Supreme Court of Appeal ${ }^{111}$ on the same dispute took matters a step further by arguing that the complexity that arises as a result of disputes moving away from the domain of collective bargaining where dismissal is not allowed in resolving matters of mutual interest to the zone of rights dispute where dismissal is permitted, emanates from the dichotomy between matters of mutual interest and matters of right. For the court such a complexity needs not arise because the dichotomy of rights and interests disputes on which such a complexity seems to emanate from, has no legal basis. In holding that such a dichotomy has no statutory basis, the court argued:

"The core difficulty with this argument is that the dichotomy between matters of mutual interest and questions of 'right' do not in our view form the basis of the collective bargaining structure that the statute has adopted. The unavoidable complexities that arise from the supposed 'migration' of issues from matters of mutual interest to matters of 'right' demonstrate in our view that the dichotomy does not form the basis of the statutory structure, and $s$

199920 ILJ 755.

110 Supra par 38.

111 National Union of Metalworkers of South Africa v Fry's Metals (Pty) Ltd (2005) 26 ILJ 689 (SCA). 
$187(1)$ (c) cannot, accordingly, be interpreted as if the legislation proceeds from that premise."

This argument is quite puzzling, because the effective resolution of disputes in terms of whether they should be classified as belonging to the collective bargaining arena or the adjudication or arbitration terrain largely relies on this dichotomy. In dealing with disputes relating to unfair labour practices, the courts, in particular the Labour Appeal Court, have also made use of this dichotomy. In terms of this finding such a reliance was grossly misplaced.

\section{Chemical Workers Industrial Union v Algorax (Pty) Ltd}

In Chemical Workers Industrial Union v Algorax (Pty) $L t d^{13}$ the court had to deal with a dispute that emanated from an employer's decision to introduce a new shift system on the basis of operational requirements. The circumstances were very similar to those of Fry's Metals v NUMSA. ${ }^{114}$ The only difference between the two cases was that in Algorax the employer coupled the dismissal with an offer of re-employment if the employees accepted the shift system. The court, leaning heavily on the Fry's Metals decision, held that the offer of re-employment clearly showed that the dismissals were not intended to be final and therefore not based on operational requirements but merely aimed at compelling the employees to accept the employer's demand. This rendered the dismissal automatically unfair since it fell squarely within the ambit of section 187(1)(c).

One of the interesting aspects about the Algorax case was that the court did acknowledge that the employer had a valid operational requirement. However, the fact that the dismissal was accompanied by an offer of reemployment meant that the real purpose behind the dismissal was to compel employees to accept its demand and not really necessitated by operational requirements. The court indicated that the mere existence of valid operational requirements did not mean that a dismissal would automatically fall outside the ambit of section 187(1)(c). Also, that the difference between a dismissal that is based on operational requirements and that intended to compel acceptance of an employer's demand is quite awkward to explain was shown as follows:

"Counsel for the respondent submitted that, where an employer has valid operational requirements to address, a dismissal cannot be one effected for the purpose of compelling the employees to accept a demand in respect of a matter of mutual interest. I do not agree. Where, for example, an employer seeks to reduce costs in his business and demands that his employees agree to work short-time, that employer has genuine operational requirements justifying the working of short-time but, without the employee's consent, he is not entitled to require them to work short-time. He can demand that they work short-time but they are not under any obligation to comply with his demand. If

112 Supra par 54.

113 Supra.

114 Supra. 
they are not prepared to work short-time and refuse to do so, a dispute may then arise between the parties on whether the employees should work overtime. That is a dispute of interest."

From the above it can be deduced that the employer would not be allowed to resort to dismissal because the dispute is a matter of mutual interest that has to be resolved through collective bargaining.

However, the court went on to say:

"Such an employer may then dismiss the employees for operational requirements in order to get rid of them permanently and employ a new workforce that will be prepared to work in accordance with the needs of his business. In such a case the employer will be dismissing the old workforce because the contracts of employment he has with them can no longer properly serve his operational requirements."

This clearly indicates that the extent to which a dismissal that is automatically unfair is ascertained largely depends on how the employer has couched the notice of dismissal. If the employees have been dismissed permanently, the dismissal is fair. If it is conditional then it is automatically unfair. This reliance on the purpose of the dismissal as a defining device to separate the two dismissals fails to appreciate the reality that both dismissals flow from the same context of proposed changes to terms and conditions of employment and the subsequent refusal by employees to accept them.

Lastly, the complexity of sifting evidence that supports a contention that a dismissal is based on operational requirements from that which lends credence to the fact a dismissal is intended to compel employees to accept his demand, was illustrated in the same case this way:

"I think that an examination of the evidence in this matter reveals that, while on the one hand, there are indications that the purpose of the dismissal was to compel the employees to agree to the employer's demand, on the other hand, there are also indications that the purpose of the dismissal was to get rid of the employees permanently."

If there was indication of an intention to dismiss the employees "permanently", a purpose that was held to be the key to distinguishing a dismissal based on operational requirements from the one intended to compel acceptance of a demand in Fry's Metals $v$ National Union of Metalworkers of South Africa ${ }^{118}$ then, to rule that the dismissal was automatically unfair, had an element of unfairness. This indicates the inadequacy of the yardstick of ascertaining whether a dismissal is permanent or conditional to determine if it falls within section 187(1)(c) and its potentially grossly unfair consequences.

\footnotetext{
Supra par 36

Supra par 37

Supra par 39

18 Supra.
} 


\section{Mazista Tiles (Pty) Ltd v National Union of Mine Workers}

In Mazista Tiles (Pty) Ltd $v$ National Union of Mine Workers ${ }^{119}$ the employer amongst other things proposed the closure of the hostel where employees were residing, discontinuation of the feeding scheme and most importantly wanted employees to be converted to independent contractors who would be self-employed, or to make the employees to work at a reduced basic wage and an incentive-based system that would be based on productivity. The employees showed willingness to accept the proposal concerning the closure of the hostel and abolition of the feeding scheme. They rejected the proposal of becoming independent contractors or "incentive" employees. This is not surprising, given the fact that in relation to employment security the prospects of independent contractors are less appealing than those of an employee. The employer then dismissed the employees on operational grounds. The court ruled that because the dismissals were final and irrevocable, they fell outside the ambit of section 187(1)(c).

Once more, the delicate task of balancing two competing interests involving an employer's right to run a business prosperously and the employees' right to employment security was put to test. In this case the proposal was not just aimed at inducing the employees to work in a different way but to give up their very employment status. This unusual situation was clearly expressed by Thompson accordingly:

"The employer was not requiring its employees to work differently; it was demanding that they relinquish their jobs and submit sooner or later to a new and hugely prejudicial from [sic] of dependent and contingent labour."

The employer's proposal struck at the core of the employees employment security. Its wish to convert employees to become independent contractors was a matter of mutual interest which should have at best been left to the collective bargaining process. Thompson makes this observation:

"While the normal rule would be that an employer is free to wrest any outcome it can via the rigours of collective bargaining, such an extraordinary outcome was being proposed here that perhaps on request it should not have escaped the gaze of the judges even if an agreement had been extracted."

What can be deduced from this case is that the employer had proposed a package of change to terms and conditions of employment. This package included closure of a hostel, abolition of the feeding scheme as well as converting employees to the independent contractor status. The employees were willing to accept a portion of the package, namely the abolition of the feeding scheme and closure of the hostel but were not willing to accept the independent contractor status. They were dismissed for that and the court held that the dismissal was fair. For the court, the defining moment was that

19 (2004) 25 ILJ 2156 (LAC).

120 "Bargaining over Business Imperatives: The Music of the Spheres after Fry's Metals" 2006 27 ILJ 716.

121 Ibid. 
the employer had shown that the dismissal was permanent, and that the proposal had potentially devastating consequences for the employees in the sense that they had to surrender their very status of employment in the interest of the employer's operational requirements and the court should have gone further than just relying on the "permanent-conditional dismissal" test. It is against this background that Thompson argues for a much stricter test:

"when parties are engaged in economic bargaining, one of them should not be allowed to pull the plug on the process by threatening the demise of the other if it does not get its way. The courts should look especially critically at the claim that a fair reason relating to the operational requirements of a business permits an employer engaged in bargaining to throw the dismissal lever if its entire package is not accepted".

\section{A critical analysis of the Labour Appeal Court and Supreme Court appeal approach}

\section{The Labour Appeal Court}

Firstly, one of the interesting things about the Labour Appeal Court's decision in Fry's Metals $v$ National Union of Metalworkers of South Africa ${ }^{123}$ was the acceptance by the court of the employer's argument that the retrenchments were purely based on operational requirements and not intended to compel the employees to accept the employer's proposed new shift system. Then the court went on to state that there is a distinction between a dismissal contemplated by section 187(1)(c) and that based on section 188(1)(a)(ii). When ascertaining the true nature of an issue in dispute, one of the useful devices is the correspondence between parties. The notice of retrenchment that was served by the employer to the employees vindicates the assertion that a dismissal that arises from the context of proposed changes to terms and conditions of employment is very difficult to categorize clearly as being motivated purely by operational requirements instead of being intended to compel employees to accept those changes, thereby falling within section 187(1)(c).

Despite the fact that the dismissal was said to be motivated by operational requirements and not intended to force the employees to accept the employer's demand, part of the notice of retrenchment served to the employees, reads as follows:

"Please note that the [appellant] does not want to retrench you and will retain

[you] in its employ provided that you agree to work the shift system."

From this it can be inferred that whilst the employer argued that the retrenchment was motivated by operational requirements, the notice simultaneously indicated that the purpose behind the dismissal was to

200627 ILJ 710.

Supra. 
secure employees' agreement to accept the new shift system. That the court decided to downplay this important dimension is puzzling.

Secondly, whilst the Labour Court ruled that section 187(1)(c) should be read widely to give protection against threats of dismissal whether conditional or permanent when proposed changes to terms and conditions of employment are in dispute, the Labour Appeal Court has adopted a literal and narrow approach of interpreting the section to apply only to conditional dismissals that are coupled with an offer of re-instatement of the employees upon acceptance of the employer's demand. This has the potential of encouraging employers, when resorting to dismissal within the collective bargaining context, to adopt a hard-line stance during negotiations about changes to terms and conditions of employment by making it absolutely clear in their correspondence with the employees or their representatives that the dismissals are final and irrevocable, so as to escape with ease, the harsh consequences of the dismissals being found to be automatically unfair. This does not augur well for a healthy industrial relations environment. Also, it is worth noting that acceptable power-play mechanisms like lock-outs do not always bring immediate results for employers in the collective bargaining process. Traditionally, dismissal, whether temporary or permanent, has been regarded as being impermissible as a tool of compulsion in the collective bargaining process. The finding that only conditional dismissal is precluded, may tempt employers to raise the possibility of dismissals when an impasse is reached in the bargaining process. The threat of dismissal, especially in an environment where unemployment is rife may be more successful than other weapons permissible in collective bargaining. This would tilt the scales unfairly in favour of employers during negotiations as the threat of dismissal, often referred to as "capital punishment" for employees would loom large.

Thirdly, the Appeal Court's decision threatens the very foundation of collective bargaining. Negotiations during the collective bargaining process often result in an impasse. As a way of getting out of the impasse, parties are permitted to use their power as a way of persuading the other side to agree to its demands. Employers have recourse to lock-out whilst employees can go on strike.

Permitting employers to use permanent dismissal within the collective bargaining context has the potential of leaving employees somehow vulnerable in the collective bargaining process. Mischke ${ }^{124}$ laments this unfortunate situation:

"The upshot of the Fry's Metals decision was to leave the door ajar for the employer, if no agreement could not be reached with the employees or their representatives, the employer could dismiss for operational requirements in terms of $\mathbf{s} 189$ in order to rid itself of its recalcitrant employees to make way for others who would do the work as the employer required."

\footnotetext{
124 "Changing Terms and Conditions of Employment - The Return of the Automatically Unfair 25 Ibid Dismissal" November 2003 13(4) Contemporary Labour Law 33.
} 
Moreover, when interpreting the scope of section 187(1)(c) the court made reference to the fact that section's origin could be traced to the 1956 Labour Relations Act's definition of the lock-out. That definition permitted the use of conditional dismissal as a tool of compulsion during the collective bargaining process. In this regard, the court also based the core of its argument on the CCAWUSA v Game Discount World ${ }^{126}$ case where the it was held that a permanent dismissal fell outside the ambit of the lock-out as contemplated by the 1956 Labour Relations Act. What is worth noting is that in that case, the court emphatically declared the use of permanent or final dismissal as being unfair within the context of collective bargaining. The court had this to say:

"That dismissal was, and was intended to be final and irrevocable. The individual applicants were not dismissed to compel or induce them to accept respondent's demand. The fact that the notice to the employees was for that purpose, does not assist the respondent. The termination should have been for that purpose ... The dismissals were therefore unlawful ... An employee is not obliged to accept changes in conditions of employment. It is manifestly unfair to dismiss him because he refuses to accept such changes."

In line with the intention of the lock-out in terms of the 1956 Labour Relations Act, only temporary dismissals constituted a fair bargaining mechanism. The Appeal Court's decision failed to appreciate the context within which the finding that permanent dismissal falls outside the lock-out definition was made. To declare that permanent dismissals fall outside the scope of section 187(1)(c) negates the very purpose that the section sought to achieve, namely to outlaw the use of dismissal as a mechanism of pressurizing employees in the context of collective bargaining.

It may well be said that by permitting the use of conditional dismissal and outlawing final dismissal in the collective bargaining process, the 1956 Labour Relations Act had a more positive influence for labour relations because to a certain degree the preservation of the employment relationship was paramount. A conditional dismissal was deemed to be fair and functional to collective bargaining since it had the desire of resuscitating the employment relationship. A permanent dismissal, which did not have the potential of reviving the employment relationship was held to be unfair. On the other hand the interpretation that permanent dismissals fall outside the scope of section $187(1)$ (c) fails to appreciate the importance of the preservation of the employment relationship. In essence, it results in the anomalous situation where an employer who, in the context of proposed changes to terms and conditions of employment bargaining, indicates that he is dismissing employees who are refusing to accept his demand permanently is not guilty of any wrongdoing whilst an employer who in the same context shows some form of empathy by indicating that dismissals will be withdrawn if employees change their minds and accept his demands, is committing the cardinal sin of an automatically unfair dismissal. This was the

\footnotetext{
Supra.

127 CCAWUSA v Game Discount World supra 165.
} 
case in Chemical Workers Industrial Union v Algorax (Pty) $L t d,{ }^{128}$ where the employer dismissed employees who refused to accept a new shift system (similar to Fry's Metals v NUMSA) but still indicated that he was prepared to take the employees back if they accepted the changed shift system. By offering to reinstate the employees if they agreed to his demand, the employer had committed a fatal mistake as the court held that this indicated that the dismissal was motivated by the desire to compel the employees to accept a demand in respect of a matter of mutual interest. This rendered the dismissal automatically unfair despite the court's acknowledgement that the employer had valid operational requirements to introduce the shift system.

Furthermore, the Appeal Court's decision has had far-reaching consequences when it comes to security of employment for employees. It is widely accepted that employees have to expect their terms and conditions of employment to be changed in order to fit with the operational requirements of a business. In Mazista Tiles (Pty) Ltd v National Union of Mine Workers ${ }^{129}$ the employer wanted to change employees to become independent contractors. The employer was in this case not just demanding that the employees perform work differently but was requiring them instead to sacrifice their jobs and opt for an insecure form of labour. The court held that by dismissing the employees who had refused to accept his demand finally and irrevocably, the employer was fully justified to do so on operational grounds. This is surely contrary to one of the purposes of the Labour Relations Act of 1995 which is to advance social justice.

Moreover, the interpretation of section $187(1)$ (c) as only applying to conditional dismissals has the potential to undermine one of the core tenets of the collective bargaining process, the collective agreements. On the basis of this interpretation, a shrewd employer can conclude what he may consider an unsustainable collective agreement with a trade union, on a wage increase, for instance, and then walk away from that agreement by dismissing the employees for operational requirements to achieve what he couldn't during negotiations. As long as the employer makes it a point that the dismissals are final, the dismissals will not be regarded as being automatically unfair. In General Food Industries Ltd v Food \& Allied Workers Union $^{130}$ the employer concluded a wage increase agreement, which it argued was not affordable, with its employees and six months later embarked on retrenchments. The court held that the retrenchments were fair and not intended to undermine the collective agreement (about wage increase).

In addition, one of the unfortunate consequences of the adulterated meaning attached to section $187(1)$ (c) by the court is that the prospects of employees or their representatives successfully relying on that section when challenging a dismissal that arises out of the context of proposed changes to terms and conditions of employment are very slim. This interpretation has

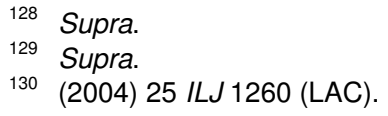


emasculated section $187(1)(c)$. With the court having declared that permanent dismissals within the context of changes to terms and conditions of employment are permissible if they are informed by operational requirements in terms of section 189 of the 1995 Labour Relations Act, employees would be well advised to complement their challenge to the dismissal on the grounds of section 187(1)(c) with a challenge that is based on unfairness in terms of section 189.

When interrogating a dismissal based on section 189 the courts are more vigilant as was evidenced by the remarks of the court in Chemical Workers Industrial Union v Algorax:

"When either the Labour Court or this court is seized with a dispute about the fairness of a dismissal, it has to determine the fairness of the dismissal objectively. The question whether the dismissal was fair or not must be answered by the court. The court must not defer to the employer for the purpose of answering that question. In other words it cannot say that the employer thinks it is fair, it is or should be fair."

By presenting a twin challenge based on section 187(1)(c) and also on section 189 the dismissed employees were able to achieve a better result in the Algorax case, unlike in Fry's Metals $v$ NUMSA ${ }^{132}$ where the challenge on dismissal was solely based on section 187(1)(c) and the court therefore did not examine whether indeed the employer considered alternatives to the dismissal properly, as prescribed by section 189.

In conclusion, the assertion that section 187(1)(c) only applies to dismissals that are conditional and not to permanent dismissals is not conducive to a healthy collective bargaining environment. Thompson ${ }^{133}$ cautions that this forces employers to take drastic action by effecting final and irrevocable dismissals rather than conditional dismissals when bargaining about proposed changes to terms and conditions of employment. This interpretation which comes down hard on employers who even by the slightest of imaginations indicate preparedness to reinstate employees has even led to a situation where the termination lock-out that was permissible under the 1956 Labour Relations Act is seen as being much preferable when compared to section 187(1)(c). Todd and Damant express this perspective succinctly:

"We have considerable difficulty understanding why the legislature should seek to protect workers by outlawing the lock-out dismissal. It may readily be contended that a lock-out dismissal is preferable by a considerable margin (from the point of view of workers) to a 'final' dismissal in the same circumstances. Fry's Metals and Algorax aptly demonstrate that the prohibition may have the effect of subverting conventional notions of what is fair in the context of an operational requirements dismissal, in particular that every effort should be made before, during or even after the dismissal to secure alternative employment for the dismissed workers."

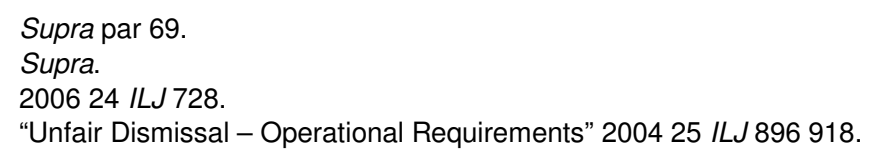


The anomaly that flows from this narrow interpretation of the meaning of section $187(1)(c)$ is aptly put by Grogan:

"It seems somewhat strange that the legislature should have categorized conditional dismissals in the context of collective bargaining as automatically unfair, but excluded final dismissals occurring in the same context. It is also debatable whether the legislature intended to allow employers to terminate collective bargaining over employer-initiated proposals by finally and irrevocably dismissing the employees."

Van Niekerk comments on the absurdity of this interpretation this way:

"The Fry's Metals judgment raises difficult issues in the intersect between collective bargaining and unfair dismissal. It does seem anomalous that an employer is protected against the consequences of exercising the power to dismiss when it need demonstrate little more than that it intended to treat the dismissals as final. It has been suggested that this power enables employers to undermine the institution of collective bargaining by resorting to dismissal as a weapon when it is unable to achieve its demands through the collective bargaining, effectively converting what is a dispute of interest into a dispute of right. It is perhaps even more anomalous that a 'temporary' dismissal (which assumes a reinstatement once the underlying dispute is resolved) should be visited with a penalty of 24 months' remuneration, while a 'permanent' dismissal, however unfair it may be, attracts the less maximum penalty of 12 months' remuneration.

The fear that employers can easily undermine the process of collective agreement by resorting to dismissal when unable to achieve their demands through the collective bargaining process, thereby effectively converting what is a dispute of interest into a dispute of right, stems from the verdict in General Food Industries Ltd v Food and Allied Workers Union. ${ }^{137}$ It can be said that the court's argument that the retrenchments that the company embarked on after concluding a wage increase agreement with the employees (albeit for fear of industrial action) had been raised even before the agreement was struck and were therefore not intended to undermine the agreement itself, does hold weight. However, the possibility of employers engaging in collective bargaining and then resorting to dismissal when unable to achieve their demands is high. To overcome the hurdle of automatically unfair dismissals, all that they have to do is to ensure that the dismissals are permanent.

Cohen, ${ }^{138}$ noting that a well-advised employer could circumvent the provisions of section 187(1)(c) by refraining from making an offer of reinstatement argues that this anomaly could have been avoided if the Labour Appeal Court had adopted a purposive interpretation which reflected the legislature's rejection of the use of dismissal as a pressure tactic to influence the outcome of an interest dispute.

\footnotetext{
Grogan "Chicken or Egg. Dismissals to Enforce Demands" 2003 19(2) Employment Law 4.

Van Niekerk and Linstrom 37.

Supra.

200425 ILJ 1892.
} 


\title{
442 The Supreme Court of Appeal
}

One of the interesting aspects of the Supreme Court of Appeal's upholding of the Labour Appeal Court's verdict in Fry's Metals $v$ National Union of Metalworkers of South Africa ${ }^{139}$ was the outright rejection of the dichotomy between matters of mutual interest and matters of right. The court stated categorically that such a dichotomy has no statutory basis. This dichotomy has been helpful in explaining whether a particular dispute should be resolved through arbitration or adjudication, or should be resolved through collective bargaining.

This dichotomy has also been extensively used by the courts, in particular the Labour Appeal Court when dealing with disputes concerning unfair labour practice in relation to provision of benefits. For instance, in Hospersa $v$ Northern Cape Provincial Administration, ${ }^{140}$ where the dispute revolved around the issue of an acting allowance the court observed:

\begin{abstract}
"A dispute of interest should be dealt with in terms of the collective bargaining structures and is therefore not arbitrable. A dispute of interest should not be allowed to be arbitrated ... under the pretext that it is a dispute of right. To do so ... would inevitably be a fundamental subversion of the collective bargaining process itself. If individuals can properly secure orders that have the effect of determining the evaluation of differing interests on the merits thereof, then the distinction between disputes of interest and disputes of right would be distorted and the collective bargaining process self-evidently would become undermined."
\end{abstract}

Also, in Gauteng Provinsiale Administrasie $v$ Scheepers ${ }^{142}$ the court referred to the dichotomy this way:

"Generally speaking a dispute relating to proposals for the creation of new rights or the diminution of existing rights is a dispute of mutual interest. Such disputes are ordinarily to be resolved by collective bargaining ..."

Furthermore, this distinction between matters of mutual interest and matters of right has been extensively referred to by legal writers in the process of explaining certain concepts. For instance, Grogan in Workplace Law, makes reference to the dichotomy in this way:

"Rights disputes are those arising from breaches of rights or failure to discharge duties expressly conferred or imposed by the Act or other statutes, by collective agreement or by individual contracts of service; they are justiciable in terms of the LRA by either arbitration or adjudication. All other disputes are matters of interest (therefore non-justiciable and of necessity to be resolved by industrial action). The Act terms these 'matters of mutual interest'."

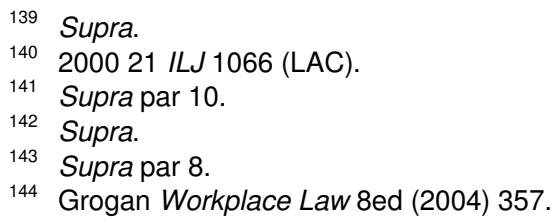


In Labour Relations Law: A Comprehensive Guide when explaining the importance of the rights-interests dichotomy when dealing with the concept of unfair labour practice in relation to benefits, Du Toit puts it as follows:

"Since unfair labour practices are disputes of right rather than interest, a dispute over benefits must amount to a dispute of right in order to be classified as an unfair labour practice."

Also, in A Guide to South African Labour Law, Rycroft and Jordaan explain the distinction this way:

"Broadly speaking, disputes of right concern the infringement, application or interpretation of existing rights embodied in a contract of employment, collective agreement, or statute, while disputes of interest (or 'economic disputes') concern the creation of fresh rights, such as higher wages, modification of existing collective agreements, etc. Collective bargaining, mediation, peaceful industrial action, are generally regarded as the most appropriate avenues for the settlement of conflicts of interests, while adjudication is normally regarded as an appropriate method of resolving disputes of right."

The dichotomy of matters of mutual interest and matters of right plays a very important role in determining the appropriate route that disputes must follow for being effective. It also plays an important role in the resolution of unfair labour practices relating to benefits, for instance. It is rather puzzling why the Supreme Court of Appeal denied the existence of such a notion.

Thompson ${ }^{147}$ is spot-on when he avers that it is somewhat baffling why the Supreme Court of Appeal was dismissive of the rights-interest dichotomy because the solution that the Labour Appeal Court adopted when interpreting the meaning of section 187(1)(c) in Fry's Metals $v$ National Union of Metalworkers of South Africa ${ }^{148}$ did not require a denial of the distinction between matters of mutual interest and matters of right. $\mathrm{He}$ emphasizes the importance of the distinction in relation to disputes relating to unfair labour practice this way:

"A good appreciation of the rights-interests distinction is indispensable in characterizing and then dealing with disputes in the context of $s$ 186(2)(a), which brands as an unfair labour practice 'unfair conduct by the employer relating to the promotion, demotion, probation ... or training of an employee or relating to the provision of benefits to an employee,.".149

In conclusion, the rejection of the rights-interest dichotomy is not helpful for effective resolution of labour disputes. Up to the point that this dichotomy was deemed to be non-existent, strictly speaking, it was relatively easy to categorize disputes in terms of whether they were of interest or right matters and consequently determine the route the followed for resolution. This also helped the courts when dealing with unfair labour practice disputes over

145 Du Toit et al 493.

46 Rycroft and Jordaan South African Labour Law (1992) 16.

147200627 ILJ 724.

148 Supra.

149200627 ILJ 724. 
provision of benefits. It is absolutely important that the courts should guard against bringing notions that have no potential of contributing positively to the effective resolution of labour disputes.

\title{
5 RECOMMENDATIONS
}

The purpose of the Labour Relations Act of 1995 is to advance, amongst other things, economic development and social justice. ${ }^{150}$ This requires that a balance be struck between safeguarding the employer's right to run his business prosperously and the employees' right to employment security. Whilst it is fair to preclude dismissal as a way of compelling employees to accept a demand in respect of any matter of mutual interest between the employer and the employee, it is also fair to acknowledge that an employer does have a right to dismiss employees whose terms and conditions of employment do not meet his operational requirements. Competitive market forces demand that employers respond by changing the terms and conditions of employment. If they fail to do so, the possibility of their enterprise facing financial ruin is quite high. At the same time to give employers unrestricted latitude through permitting them to dismiss employees on operational grounds, in relation to changing terms and conditions of employment, would be greatly prejudicial to employees and would not be favourable for collective bargaining.

The options that employers have in terms of effecting changes to the terms and conditions of employment, namely negotiating with the employees and the lock-out are not always effective. This is what makes employers find it hard to resist the temptation of evading the collective bargaining and instead resorting to dismissal. Mischke illustrates this:

\begin{abstract}
"But bargaining also takes time, often a lot of time, and again there is no guarantee that this method of changing terms and conditions of employment will have the required effect. Collective bargaining can be delayed or deadlock reached, leaving the employer potentially in a worse situation than it started off with. In theory of course, the employer may contemplate exercising economic power in the form of a lock-out - hardly the most appropriate course of action for an employer already facing considerable economic pressure. The resulting loss of production and the fall-out of a lock-out may very well constitute the last straw for a struggling employer. Because the employer needs to move quickly, dismissal comes to mind as an alternative: if all else fails, the threat of dismissal or the reality of a dismissal may be the most appropriate method of placing pressure on the employees and their trade union to accede to the employer's demands for changes to the terms and conditions of employment. If for example, the employees do not agree to a new shift system, different ways of working overtime, standby allowances or other issues, the threat of dismissal and subsequent unemployment may succeed where other methods of persuasion have failed.
\end{abstract}

The interpretation of section 187(1)(c) by the courts and its anomalous consequences has resulted in a need to come up with some options that

\footnotetext{
S 1.

151 Mischke November 2003 13(4) Contemporary Labour Law 32.
} 
may be beneficial to both employers and employees and, most importantly, to preserve the sanctity of collective bargaining.

\section{Removal of section 187(1)(c) from the category of automatically unfair dismissals}

The confinement of section 187(1)(c) to conditional dismissals has resulted in anomalous situations where within the context of proposed changes to terms and conditions of employment, the mere fact that a dismissal is permanent suffices to exonerate it from being automatically unfair whilst that which is coupled with an offer of re-employment does not. Given the harsh sanctions that flow from an automatically unfair dismissal, in the context of proposed changes, it is quite logical to argue that meting out the severe sanctions to an employer whose only wrongdoing is indicating that he is prepared to take the dismissed employees back if they accept his demands whilst exonerating the employee who categorically indicates that the dismissal is permanent, is highly unfair. It is against this background that Thompson suggests that section 187(1)(c) should be removed from the category of automatically unfair dismissals. He reasons:

"Option one could be to remove the prohibition of against tactical and temporary dismissals from the category of automatically unfair dismissals. It simply does not belong there and spawns anomalies. In fact, it probably does not belong anywhere else either. The shoulders of $s$ 188(1)(a)(ii) are broad enough to deal with the fairness of all dismissals in the operational requirements context, and strong enough to give all dismissals that subvert the bargaining process, whether temporary or permanent, their proper due.

By their very nature, operational requirements dismissals are "no fault dismissal" on the employees' part. Stringent conditions must be satisfied before a dismissal based on operational requirements can be declared to be fair. Section 189 gives effect to this notion by expecting employers, amongst other things, to consider alternative measures to avoid the dismissals. For instance, section 189A(19) (applicable to large scale retrenchments) stipulates the following conditions that must be met for a dismissal that is based on operational requirements:

- The dismissal must be effected to give effect to a requirement based on the employer's economic, technological, structural or similar needs.

- The dismissal must be operationally justifiable on rational grounds.

- There must be proper consideration of alternatives.

- Selection criteria must be fair.

It has to be said that when it comes to probing the fairness of operational requirements, the court are quite vigilant. Mischke attests to this sentiment this way:

52 Thompson 200627 ILJ 730. 
"The days in which the Court hesitated to rush headlong into an evaluation of the employer's business decision are long gone. No such judicial reticence now prevails. It has been replaced by an avid judicial scrutiny and attention to the details of the employer's business reasoning and decision-making."

Concerning the role of the courts when probing dismissals based on operational requirements, in BMD Knitting Mills (Pty) Ltd $v$ SACTWU ${ }^{154}$ the court had this to say:

"The word 'fair' introduces a comparator, that is a reason which must be fair to both parties affected by the decision. The starting point is whether there is a commercial rationale for the decision. But, rather than take such a justification at face value, a court is entitled to examine whether the particular decision has been taken in a manner which is also fair to the affected party, namely the employees to be retrenched. To this extent the court is entitled to enquire as to whether a reasonable basis exists on which the decision, including the proposed manner, to dismiss for operational requirements is predicated. Viewed accordingly, the test becomes less deferential and the court is entitled to examine the content of the reasons given by the employer, albeit that the enquiry is not directed to whether the reason offered is the one which would have been chosen by the court. Fairness, not correctness is the mandated test."

In Chemical Industrial Workers Union v Algorax (Pty) $L t d^{155}$ the court held:

"Sometimes it is said that a court should not be critical of the solution that an employer has decided to employ in order to resolve a problem in its business because it normally will not have the business knowledge or expertise which the employer as a businessperson may have to deal with problems in the workplace. This is true. However, it is not absolute and should not be taken too far. When either the Labour Court or this court is seized with a dispute about the fairness of a dismissal, it has to determine the fairness of the dismissal objectively. The question whether the dismissal was fair or not must be answered by the court. The court must not defer to the employer for the purpose of answering that question. In other words it cannot say that the employer thinks it is fair, and therefore, it is or should be fair."

To further bolster the argument that the courts are quite interrogative and considerate of the plight of employees when dealing with an unfair dismissal based on operational requirements, it is important to note that in some cases the court has even gone to the point of saying that dismissal should be the last resort.

For instance, in General Food Industries Ltd $v$ Food \& Allied Workers Union $^{156}$ the court held:

"After consultations have been exhausted the employer must decide whether to proceed with the retrenchments or not. The loss of jobs through retrenchment has such a deleterious impact on the life of workers and their families that it is imperative that - even though reasons to retrench employees may exist - they will only be accepted as valid if the employer can show that all viable alternative steps have been considered and taken to prevent the retrenchments or to limit these to a minimum."

\footnotetext{
November 2003 13(4) Contemporary Labour Law 36.

20017 BLLR 705 par 19.

155 Supra par 69.

156 Supra par 55.
} 
Also, in Chemical Industrial Workers Union v Algorax ${ }^{157}$ the court declared as follows:

"It seems to me that the reason for the lawmaker to require all of these things from the employer was to place an obligation on the employer only to resort to dismissing employees for operational requirements as a measure of last resort. If that is correct, the court is entitled to intervene where it is clear certain measures could have been taken to address the problems without dismissals for operational reasons or where it is clear that dismissal was not resorted to as a measure of last resort."

In short, the removal of the dismissal intended to compel employees to accept an employer's demand from the category of automatically unfair dismissals would not leave employees without protection. Dismissals emanating from operational requirements are scrutinized by the courts and a dismissal that is disguised as an operational requirement one whilst it is not, will not pass muster easily. Therefore, the anomalies brought about by the narrow interpretation of section $187(1)(\mathrm{c})$, namely that it only covers conditional dismissals and exonerates permanent dismissals, which makes it somewhat easy for employers to evade the collective bargaining process, would be obviated.

\section{Use of the "causation" test}

It is not easy to distinguish within the context of proposed changes to terms and conditions of employment a dismissal that is genuinely based on operational requirements from one that is intended to compel employees to agree in respect of a matter of mutual interest. Reliance on whether the dismissal is final or conditional is simply not the best option. It is very easy to meet that condition. It also has the potential of negating collective bargaining through giving employers a leeway of moving away from the bargaining process through resorting to dismissal on the basis of operational requirements. As a way of closing the gaps created by the operational requirements ground of dismissal, Cohen ${ }^{158}$ argues for the use of the "causation test" when examining, within the context of proposed changes to terms and conditions of employment, whether a dismissal is based on operational requirements or is aimed at compelling employees to accede to an employer's demand. This test was used in South African Chemical Workers Union $v$ Afrox $L t d,{ }^{159}$ where employees had embarked on a protected strike and the employer dismissed them on the grounds of operational requirements. The question that the court had to answer was whether the employees were dismissed because of their participation in the strike or because of genuine operational requirements. Using the causation test, the court arrived at the conclusion that the employees were not dismissed for their participation in the strike, but for operational requirements.

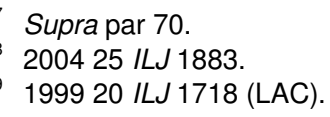


The test has two legs:

- the factual causation; and

- the legal causation.

\section{(a) The factual causation}

In terms of the factual causation leg, the question that has to be asked is whether the employees would have been dismissed if the employer had not attempted to introduce changes to their terms and conditions of employment. If the answer is that the dismissals would have taken place even if the employer had not proposed changes to the terms and conditions of employment, then the dismissal would not be automatically unfair.

If the answer is that that the dismissal would not have taken place if the employer had not proposed the changes, this does not immediately render the dismissal automatically unfair. The enquiry moves to the next stage, the legal causation.

\section{(b) The legal causation}

In the legal causation leg, the enquiry is whether the proposed changes to the terms and conditions of employment were the "main" or "dominant" reason behind the dismissal. The answer to the enquiry depends on the purpose of the change and the reason behind the dismissal. If, from the enquiry, it cannot be inferred that the dismissal was intended to compel employees to accept the employer's demand, the next stage should be to bring in section 189 to ascertain whether the dismissal was effected for a fair reason based on operational requirements and also whether a fair procedure was followed.

Given the tough interrogation that dismissals based on operational requirements are exposed to by the courts, section 189 serves as a reliable tool that can be used to distinguish a dismissal genuinely based on operational requirements from that which is meant to secure employees' compliance with a demand.

In conclusion, the use of the causation test would be very helpful in establishing the real purpose behind a dismissal. It would also obviate an unfortunate situation like in Chemical Industrial Workers Union v Algorax, ${ }^{160}$ where, despite the court's admission that the employer had a valid operational requirement to dismiss, the dismissal was found to be automatically unfair merely because the employer had indicated willingness to re-employ the dismissed employees if they accepted his demand. The causation test would have established the main or proximate reason behind the dismissal and certainly the offer of re-employment would not have been the main indicator that the dismissal was automatically unfair.

160 Supra. 


\section{USE OF REPLACEMENT LABOUR IN EMPLOYER- INITIATED LOCK-OUTS}

One of the tools that an employer is legally permitted to use in compelling employees to accept a demand in respect of any matter of mutual interest between the employer and the employee is the lock-out. Within the context of proposing changes to employees' terms and conditions of employment, an employer is legally entitled to use the lock-out as a mechanism of compulsion. Courts have consistently emphasized this. In CCAWUSA $v$ Game Discount World Ltd' ${ }^{161}$ the court said:

"An employee is not obliged to accept changes in conditions of employment. It is manifestly unfair to dismiss him because he refuses to accept such changes. The Act provides a means of compulsion, namely lock-outs."

Also, in Schoeman $v$ Samsung Electronics (Pty) $L t d^{162}$ the lawfulness of a lock-out as a weapon of compulsion was reiterated:

"An employer needs the flexibility to deploy, reasonably, quickly and efficiently, the resources at the employer's disposal. Options are open to an employer to achieve this. One of them is the lock-out route which is used to compel acceptance of a demand. It is recognized that in a collective bargaining situation (and I would add in an individual bargaining situation) an employer may bargain and exercise economic power against employees."

Despite the ready availability of the lock-out as a means of compelling employees to accept a demand in respect of any matter of mutual interest between the employer and the employee, it is its ineffectiveness that makes it to be less appealing to employers. This is what makes dismissal a tempting option to employers.

One of the factors that make the lock-out to be ineffective, particularly when it comes to compelling employees to accept proposed changes to their terms and conditions of employment, emanates from the issue of replacement labour. The use of replacement labour within the lock-out context is regulated by section 76 of the Labour Relations Act of 1995.

Section 76(1)(b) reads thus:

"An employer may not take into employment any person - ... for the purpose of performing the work of any employee who is locked out, unless the lock-out is in response to a strike."

In terms of this section, if there is a dispute about changes to terms and conditions of employment, an employer who initiates a lock-out before the employees have embarked on a strike, will not be entitled to engage replacement labour. This could have serious implications because production could virtually come to a halt if the majority or all the employees are locked out. Even if not all the workers are locked out, the options of the

\footnotetext{
Supra 165.

Supra par 18

S 76(1)(b) of the 1995 Labour Relations Act.
} 
employer in terms of relying on the employees who are not locked out are limited. Unless the employees who are not locked out show willingness to do the work of the locked out employees, the employer cannot compel them through dismissal.

Section $187(1)(b)$ reads as follows:

"A dismissal is automatically unfair if the employer, in dismissing the employee acts contrary to section 5 or if the reason for the dismissal is - ... that the employee refused, or indicated an intention to refuse, to do any work normally done by an employee who at the time was taking part in a strike that complies with the provisions of Chapter IV or was locked out, unless that work is necessary to prevent an actual danger to life, personal safety or health."

These constraints in relation to the use of replacement labour, make the lock-out to be least attractive. The compounding of matters is also the fact that an employer is not allowed to introduce changes to the employees' terms and conditions of employment unilaterally. He has to obtain their consent or resort to the lock-out option. Given the harsh sanctions that await an employer who dismisses employees who refuse to perform the work of employees who are locked out, it would be foolhardy for an employer to take such a step as a way of ensuring that production is not hampered by the lock-out. Cases where work is necessary to prevent an actual danger to life, personal safety or health (where the employer is permitted to dismiss an employee who refuses to perform the work of an employee who is locked out) are few and far between. It is a combination of these factors that makes dismissal an attractive option for employers.

Todd and Damant ${ }^{165}$ illustrate the unintended consequences of the prohibition of replacement labour in employee-initiated lock-outs:

"The employer's ability to use the lock-out as a means of compulsion at the point of impasse has been severely curtailed by the prohibition on the use of replacement labour in employer initiated lock-outs. It could be argued that dismissal would, in the circumstances under discussion, not be justifiable for as long as the employer could reasonably be expected to engage temporary alternative labour in place of the existing workforce. The employer could be expected to continue with the power-play rather than dismiss for as long as it could reasonably continue its business by using replacement labour. But the prohibition on the use of replacement labour in employer initiated lock-outs has the effect that an employer may find itself more quickly at the point where it is operationally and commercially justifiable on rational grounds to jettison the existing recalcitrant workforce and go to the cost and effort of replacing it and training a new workforce, rather than continuing to hold out with the existing workforce at the point of impasse."

However appealing as the dismissal option may be to employers, it is also has its own problems. Needless to say, for employees dismissal is the worst form of punishment. For employers, dismissals can also be costly. Todd and Damant ${ }^{166}$ point this out:

\footnotetext{
S 187(1)(b) of the 1995 Labour Relations Act. 200425 ILJ 919.

200425 ILJ 920.
} 
"Where it is operationally and commercially justifiably on rational grounds to do so, an employer may choose to dismiss in these circumstances provided its intention in doing so is clearly to replace those workers who refuse to accept the workplace changes demanded, and is not to attempt to force compliance with its demands. Of course replacing a workforce is unlikely to be an attractive option for most employers. The loss of accumulated skills and the cost of recruitment and training are likely to have a material impact on the business. And the employer may be obliged to pay severance benefits to the retrenched workforce."

The prohibition of use of replacement labour emasculates the lock-out option as a bargaining mechanism. This leads to the unfortunate situation which compels employers to resort to dismissal on operational grounds. Dismissal is costly for the employees as they lose their source of livelihood. It also has expensive consequences for some employers as they have to contend with costs associated with recruiting and training the new employees who replace those dismissed.

Permitting the use of replacement labour in employer initiated lock-outs would make the lock-out option attractive to the employers. They would be able to exert pressure on employees using the lock-out but with production uninterrupted through the use of replacement labour. Admittedly, this would not be good news for employees, but when compared to dismissal, the use of replacement labour may not be the best option but certainly it would not be the worst option either. It is for this reason that Todd and Damant ${ }^{167}$ argue:

"It would be more sensible, in our view, for the legislature to permit the use of replacement labour in employer initiated lock-outs. This would make it more difficult for employers to argue that they have reached the point of dismissal before they have exhausted attempts at resolving the issue through industrial action. The prohibition on the lock-out dismissal would then have greater effect. The employer can only dismiss once it has reached the point in the collective bargaining process when its operational requirements justify replacing the workforce altogether, with all the cost and inconvenience that this entails to the employer. Where power-play offers a realistic possibility of achieving that result, employers will be more likely to pursue that option rather than resorting to dismissal. And dismissal may be less easy to characterize as commercially justifiable on rational grounds when the lock-out option has not been exhausted."

In conclusion, the prohibition on the use of replacement labour in employer initiated lock-outs serves no useful purpose in collective bargaining within the context of proposing changes to the terms and conditions of employment. It emasculates the lock-out, a bargaining mechanism that is legally available to the employer, to a point where it becomes so ineffective that the employer feels justified in resorting to dismissal which may actually yield the desired results. Whilst it is intended to protect the employees' bargaining position in the collective bargaining process, it leaves the very employees it seeks to protect, vulnerable to dismissal. That dismissal is detrimental to the welfare of employees cannot be disputed. It is also undeniable that for some, if not most employers, dismissals can result in costs in the form of recruitment and training costs. Indeed, dismissal is not

167200425 ILJ 921. 
conducive to a healthy industrial relations environment. It is also worth noting that for an employer who is faced with rampant market forces that demand alterations to the employees' terms and conditions of employment concerns about a healthy industrial relations climate, potential costs of dismissal, effects of the dismissal on the employee, may eventually give way to the employer's operational requirements considerations which may be best served by changing the employees' terms and conditions of employment. Whilst having recourse to a lock-out option (that for all intents and purposes is ineffective because of the prohibition on use of replacement labour), the employer may find solace in the dismissal for the operational the requirements option. Unpalatable as the use of replacement labour is for employees who are locked out or involved in a strike, when one looks at the bigger picture, permitting the use of replacement labour would be much better for the collective bargaining process. It would result in a robust but at the same time relatively fair power-play exercise. It would to a certain extent take dismissal out of the equation. It is against this background that it is ideally necessary to permit the use of replacement labour in employerinitiated lock-outs.

\section{$6 \quad$ CONCLUSION}

Competitive market forces often compel employers to propose changes to the employees' terms and conditions of employment. Employers are not permitted to introduce such change unilaterally. Consent of employees has to be obtained. The employer has to negotiate with the employees. This is where collective bargaining fits in. It is not very often that employees will appreciate the need for a change to their terms and conditions of employment. If negotiations fail to produce the desired result for the employer, then the question is what options the employer can rely on to induce the employees to accept the need for the change to their terms and conditions of employment.

The employer can make use of the lock-out option. However, if he initiates the lock-out, he is not entitled to the use of replacement labour. The 1995 Labour Relations Act is very clear on that. ${ }^{168}$ The lock-out may take a very long time if the employees do not capitulate. At the same time, production would have come to a halt. This in a way shows that the lock-out option may fail to produce positive results for the employer.

The next question is whether the employer can use dismissal as a way of pressurizing the employees to accept his demand. Dismissal is not permissible in disputes revolving around matters of mutual interest. Dismissals are not a legitimate instrument of coercion in the collective bargaining process. ${ }^{169}$ Under the 1956 Labour Relations Act, an employer, was permitted within the context of a lock-out to dismiss employees as a way of compelling them to accept a demand. However, such dismissal had to be coupled with an offer of re-employment upon acceptance of the

$168 \mathrm{~S} 76(1)(\mathrm{b})$.

169 National Union of Metalworkers of South Africa v Fry's Metals (Pty) Ltd supra par 38. 
demand. The 1995 Labour Relations Act does not offer such an option. Use of dismissal as a means of compelling employees to accept an employer's demand is strictly prohibited. Section 187(1)(c) of the 1995 Labour Relations Act gives effect to this notion by stating that a dismissal that is intended to compel an employee to accept a demand in respect of any matter of mutual interest between the employer and the employee, is automatically unfair. Therefore, if the employee resorts to dismissal, the dismissal will be automatically unfair.

An employer is allowed to dismiss employees on the grounds of operational requirements, provided that he follows a fair procedure. ${ }^{170}$ Proposed changes to terms and conditions of employment fall within the range of mutual interest where use of dismissal is not permissible. However, the very terms and conditions of employment can become matters of right. In essence, the employees' terms and conditions of employment must be responsive to the operational needs of the employer's business. If they are not the employer is allowed to dismiss those employees on the grounds of operational requirements.

It is this intersection between matters of mutual interest and matters of right that gives rise to the problem of how to determine within the context of collective bargaining and in relation to effecting changes to employees, terms and conditions of employment to be specific, whether a dismissal is intended to compel employees to accept an employer's demand (thereby falling squarely within section $187(1)$ (c) or is genuinely based on operational requirements).

The fact that in both cases the dismissal is precipitated by the need to effect changes to terms and conditions, and fully aware of the intention of section 187(1)(c) to outlaw dismissal as a bargaining mechanism. It is not surprising that Cheadle et al ${ }^{171}$ observe:

"Section 187(1)(c) makes the classic lock-out dismissal automatically unfair. An employer may no longer dismiss employees to compel them to accept new terms and conditions of employment. But how different is that from dismissing an employee on the grounds of operational requirements because the employer needs to change a term or condition of employment and the employee refuse to agree to it?"

The difficulty in distinguishing a dismissal that is based on operational requirements from that whose intention is to compel employees to accept an employer's demand has resulted in an examination of the meaning of section 187(1)(c).

The Labour Appeal Court ${ }^{172}$ as well as the Supreme Court of Appeal ${ }^{173}$ has ruled that the only dismissal that section 187(1)(c) targeted was a conditional dismissal that is subject to being withdrawn upon the employees'

170 S 188(1)(a)(ii).

17126.

172 Fry's Metals (Pty) Ltd v National Union of Metalworkers of South Africa supra.

173 National Union of Metalworkers of South Africa v Fry's Metals (Pty) Ltd 200526 ILJ 689 (SCA). 
acceptance of an employer's demand. This offer is said to be indicative of the real purpose of the dismissal, namely to compel the employees to accept a demand. Dismissals that are final and not coupled with any offer of reemployment are not automatically unfair. In essence, section 187(1)(c) was only intended to remove the option of resorting to a dismissal lock-out as an acceptable bargaining tool of the employer in terms of the 1956 Labour Relations Act, according to the superior courts. Within the context of collective bargaining only those dismissals that are accompanied by an offer of re-employment are automatically unfair. To be precise, permanent dismissals are a genuine indicator of the purpose of dismissing for operational requirements.

The test that says that when ascertaining the real purpose behind a dismissal, regard should be had to whether the dismissal is permanent or conditional, is not satisfactory. It has the potential of treating differently employers who for all intents and purposes dismissed employees for the same reason, to effect changes to terms and conditions of employment because of operational requirements but only differed when it came to couching the dismissal as being final and irrevocable or conditional. In Fry's Metals $v$ National Union of Metalworkers of South Africa ${ }^{174}$ the dismissal was held to be fair because it were final and thus indicative of a genuine operational requirement, and thus fair. In Chemical Industrial Workers Union $\checkmark$ Algorax, ${ }^{175}$ despite the court's concession that the employer did have a valid operational requirement to dismiss, the dismissal was held to have been effected for the purpose of compelling employees to accept a demand and therefore automatically unfair.

Todd and Damant ${ }^{176}$ have this to say:

"What is prohibited by $\mathrm{s} 187(1)(\mathrm{c})$ is a dismissal whose purpose is to compel acceptance of an employer's collective bargaining demand. This removes the ability of an employer to have recourse to a particular form of power-play that was frequently used prior to 1995: the termination of contracts of employment and simultaneous offer of re-employment on changed terms and conditions where the purpose is to compel acceptance of those terms and conditions.

That this is the purpose of a dismissal may be indicated by the employer's express words to this effect, or by its conduct in, for example, indicating its willingness to re-employ those of the dismissed workers who subsequently agree to accept the demand, ... However, it must be said that these are far from reliable indicators of the employer's purpose. An employer may as a matter of good faith indicate that despite the dismissal it will re-employ workers who change their mind for as long as it has not been able to replace them with new permanent employees. It would hardly be fair to conclude that this taints the employer's real objective, which is to find a replacement workforce willing to work on the new terms."

The implications of the meaning of section 187(1)(c) as interpreted by the superior courts are far-reaching. They leave an impression that the courts never really understood the real intention of the section. The true intention of section 187(1)(c) was to outlaw the use of any form of dismissal, both

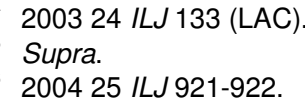


conditional or permanent, as a bargaining tool. It would be surprising to claim that this section only sought to outlaw those dismissals that were coupled with an offer of re-employment and exonerate those that are permanent. Conditional dismissals, by their nature, seek to revive the employment relationship and are in a way functional to collective bargaining. Permanent dismissals do not show any willingness to revive the employment relationship and are therefore not functional to collective bargaining.

The narrow and literal interpretation of section 187(10(c) by the superior courts have resulted in a situation where the wisdom of outlawing dismissal lock-out which is far better than a permanent dismissal is strongly questioned. Whilst the outlawing of a dismissal lock-out had noble intentions of improving the bargaining strength of employees, the interpretation of section 187(1)(c) has had the opposite effect. At least under the 1956 Labour Relations Act, the offer of re-employment was available within the context of bargaining. As things stand now, the dismissals are final and not subject to being withdrawn.

It is this anomalous situation that has resulted in calls for the following measures:

- Removal of section 187(1)(c) from the automatically unfair dismissals category.

- Removal of the prohibition on the use of replacement labour in employer initiated lock-outs.

- Use of the causation test, which is somewhat stricter than the "purpose" test.

However, the superior courts have ruled that section 187(1)(c) only impacts on conditional dismissals. Employers have to ensure that when dismissing within the context of collective bargaining, there is no indication of any intention to re-employ the dismissed employees. In this way, the dismissal will be out of the reach of section 187(1)(c). The implications of this interpretation for collective bargaining are quite ghastly. The possibility of employers, during negotiations, raising the threat of permanent dismissals on operational requirements ground (which the courts have ruled are permissible), when they do not get their way, are quite high. One would have thought that the courts would have been much stricter when ascertaining whether a dismissal, that arises within the context of collective bargaining, is really based on operational requirements or is used to compel employees to accept a demand.

- Given the fact that one of the purposes of the 1995 Labour Relations Act is to advance social justice, ${ }^{177}$ the courts should have shown greater appreciation for the inherent nature of inequality that characterizes the employer-employee relationship. By not doing so the courts prejudiced the employees' bargaining strength through a narrow interpretation of section $187(1)(c)$ which only serves to give employers an upper hand in the

177 S 1. 
collective bargaining process by permitting them to resort to permanent dismissals when they do not succeed easily in collective bargaining, under the guise of operational requirements.

Thompson ${ }^{178}$ sums the position up aptly:

"Given that any economic consideration, from basic viability to abundant profit, may qualify as an operational requirement, there is no item of collective bargaining immune to the negotiating attack that non-acceptance of a demand may end in dismissal tears. If an employer may, in the very bargaining process, raise the spectre of dismissal in relation to wages and benefits and anything else, not much remains of a protected right to strike either. The courts, it is suggested, should regard the operational requirements claim with a healthy measure of scepticism, and use the fairness filter to sort the chaff from the corn."

178200627 ILJ 710. 